\title{
Adenovirus: Epidemiology, Global Spread of Novel Serotypes, and Advances in Treatment and Prevention
}

\author{
Joseph P. Lynch III, MD ${ }^{1}$ Adriana E. Kajon, PhD² \\ ${ }^{1}$ Division of Pulmonary, Critical Care Medicine, Allergy, and Clinical \\ Immunology, Department of Internal Medicine, The David Geffen \\ School of Medicine at University of California, Los Angeles, \\ Los Angeles, California \\ 2 Department of Infectious Disease, Lovelace Respiratory Research \\ Institute, Albuquerque, New Mexico
}

\begin{abstract}
Address for correspondence Joseph P. Lynch, III, MD, Division of Pulmonary, Critical Care Medicine, Allergy, and Clinical Immunology, Department of Clinical Medicine, Step VIII, The David Geffen School of Medicine at University of California, Los Angeles, 10833 Le Conte Avenue, Room CHS 37-131, Los Angeles, CA 90095 (e-mail: jplynch@mednet.ucla.edu).
\end{abstract}

Semin Respir Crit Care Med 2016;37:586-602.

\begin{abstract}
Keywords

- adenovirus

- respiratory viral infections

- serotypes

- cidofovir

Adenoviruses (AdVs) are DNA viruses that typically cause mild infections involving the upper or lower respiratory tract, gastrointestinal tract, or conjunctiva. Rare manifestations of AdV infections include hemorrhagic cystitis, hepatitis, hemorrhagic colitis, pancreatitis, nephritis, or meningoencephalitis. AdV infections are more common in young children, due to lack of humoral immunity. Epidemics of AdV infection may occur in healthy children or adults in closed or crowded settings (particularly military recruits). The disease is more severe and dissemination is more likely in patients with impaired immunity (e.g., organ transplant recipients, human immunodeficiency virus infection). Fatality rates for untreated severe AdV pneumonia or disseminated disease may exceed $50 \%$. More than 50 serotypes of AdV have been identified. Different serotypes display different tissue tropisms that correlate with clinical manifestations of infection. The predominant serotypes circulating at a given time differ among countries or regions, and change over time. Transmission of novel strains between countries or across continents and replacement of dominant viruses by new strains may occur. Treatment of AdV infections is controversial, as prospective, randomized therapeutic trials have not been conducted. Cidofovir is the drug of choice for severe AdV infections, but not all patients require treatment. Live oral vaccines are highly efficacious in reducing the risk of respiratory AdV infection and are in routine use in the military in the United States, but currently are not available to civilians.
\end{abstract}

\section{Adenovirus}

In 2011, we published a comprehensive review of adenovirus (AdV) infections in this journal ${ }^{1}$; this article updates new developments since that review. AdVs most often infect the upper or lower respiratory tracts, conjunctiva, or gastrointestinal (GI) tract. ${ }^{1-4}$ More than $80 \%$ of diagnosed AdV infections occur in children $<4$ years old (due to lack of humoral immunity). ${ }^{2,3,5,6}$
Immunosuppressed persons $s^{2,7-9}$ are more susceptible. ${ }^{3,10-15}$ High baseline immunity against AdV (IgG titer of $\geq 1: 32$ ) confers substantial protection. ${ }^{16} \mathrm{AdV}$ infections may occur in healthy children $^{3,10-13}$ or adults in closed or crowded settings (particularly military recruits). ${ }^{17-21}$ The vast majority of cases are selflimited. However, the clinical spectrum is broad, and dissemination or pneumonia can be fatal, both in immunocompetent $^{22,23}$ and immunocompromised patients. ${ }^{2,9,24-28}$
Issue Theme Respiratory Viral Infections; Guest Editor: Sunit K. Singh, PhD
DOI http://dx.doi.org/ 10.1055/s-0036-1584923. ISSN 1069-3424. 


\section{Virology}

Human AdVs are a group of double-stranded nonenveloped DNA viruses belonging to the genus Mastadenovirus of the Adenoviridae family. ${ }^{29,30}$ Currently, 51 serotypes, and over 70 genotypes defined by bioinformatics analysis of complete genomic sequences and designated with consecutive numbers $(52,53,54$, etc.) have been described and classified within 7 species (HAdV-A through HAdV-G). ${ }^{31-37}$ Species A, $B, C, D, E$, and F circulate globally, and have been implicated in outbreaks of infection in humans. ${ }^{1}$ Different genome types (or genomic variants) can be distinguished within the same serotype by restriction enzyme analysis of genomic DNA. ${ }^{38-40}$ Approximately one-third of the described serotypes are associated with human disease. ${ }^{24,26,29,31,41-44}$ Different serotypes display different tissue tropisms that correlate with clinical manifestations of infection ${ }^{2,26,31,33}$ (discussed in detail in the next sections).

\section{Epidemiology}

AdVs may cause epidemics of febrile respiratory illness (FRI), pharyngoconjunctival fever, ${ }^{45}$ keratoconjunctivitis (KC), ${ }^{46-49}$ or gastroenteritis and diarrheal illness. ${ }^{50-61}$ Severe or disseminated AdV infections may occur in immunocompromised hosts ${ }^{7,9,62-64}$ and rarely in immunocompetent patients. ${ }^{23,65}$

Most epidemics occur in the winter or early spring, ${ }^{6}$ but infections occur throughout the year with no clear seasonality. ${ }^{2}$ Infection can result from exposure to infected individuals (inhalation of aerosolized droplets, conjunctival inoculation, fecal oral spread), $, 2,66,67$ acquisition from exogenous sources (e.g., pillows, linens, lockers, guns), ${ }^{68,69}$ or reactivation. ${ }^{2,26}$ Incubation period ranges from 2 to 14 days. ${ }^{2}$ Importantly, latent AdV may reside in lymphoid tissue, ${ }^{7,70}$ renal parenchyma, ${ }^{71}$ or other tissues for years; reactivation may occur in severely immunosuppressed patients. ${ }^{7,70,71}$ Asymptomatic carriage of AdV may persist for weeks or months. ${ }^{31,72,73}$ Epidemics may spread rapidly among closed populations ${ }^{16,17,20,33,40,44,68,74-76}$ (e.g., hospitals, ${ }^{6,67,77}$ neonatal nurseries, ${ }^{78}$ psychiatric $^{77,79}$ or longterm care facilities, ${ }^{48,66,80}$ job training centers, ${ }^{21}$ boarding schools or dormitories, ${ }^{81}$ a children's home, ${ }^{82}$ orphanages, ${ }^{83}$ public swimming pools ${ }^{84,85}$ ). In institutionalized settings, infection control measures and cohorting may be essential to limit spread. ${ }^{66,67,86} \mathrm{AdV}$ is resistant to many disinfectants ${ }^{87}$ but $95 \%$ ethanol solution is an effective disinfectant. ${ }^{73}$

\section{Clinical Features of Adenovirus Infection}

\section{Respiratory Tract Involvement}

AdV accounts for at least 5 to $10 \%$ of pediatric and 1 to $7 \%$ of adult respiratory tract infections (RTIs). ${ }^{2,31}$ Typical symptoms of AdV RTI include fever, pharyngitis, tonsillitis, cough, and sore throat. ${ }^{3,19} \mathrm{GI}$ symptoms may be present concomitantly, particularly in children., $13,19,88$ In immunocompetent patients, symptoms usually abate spontaneously (within 2 weeks) and infection induces type-specific immunity. ${ }^{2}$ Pneumonia occurs in up to $20 \%$ of newborns and infants, $3,10,12,88,89$ but is uncommon in immunocompetent adults. ${ }^{2,16,17,77,79,90,91}$ However, fatalities due to
AdV pneumonia have been described in previously healthy children ${ }^{10}$ or adults. ${ }^{19,23,65,79,90}$ In immunocompromised persons, dissemination and/or severe respiratory failure develop in 10 to $30 \%$ of cases ${ }^{2,9,27,38}$ and fatality rates for severe AdV pneumonia may exceed $50 \%$ 2,9,90 (- Fig. 1).

In children, long-term respiratory sequela of AdV RTI include bronchiectasis, bronchiolitis obliterans, and hyperlucent lung. ${ }^{92-94}$ AdVs have a propensity to establish latent or
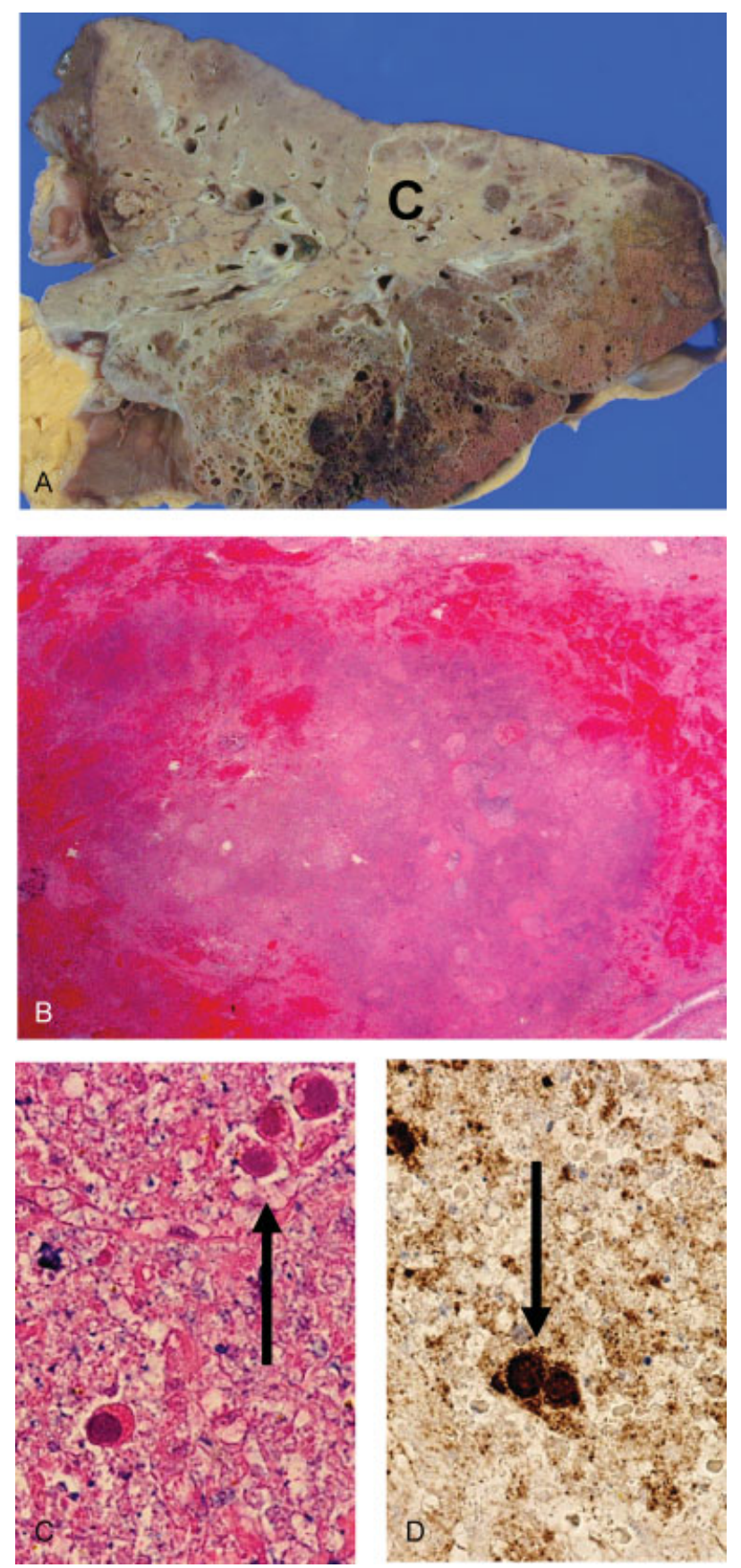

Fig. 1 Fatal case of adenovirus pneumonia. (A) Gross lung with pale, consolidated region, C. (B) Histopathology showing hemorrhagic necrotic lung tissue (hematoxylin and eosin [H\&E] stain $\times 40$. (C) High magnification showing three cells with intranuclear inclusions (arrow) (H \& E) stain $\times 400$. (D) Immunohistochemical staining for adenovirus showing positive staining of the intranuclear inclusions in two cells (arrow) (immunoperoxidase $\times 400$ ). (Reproduced with permission from Lynch et al. ${ }^{1}$ ) 
persistent infection within the upper ${ }^{95}$ and lower respiratory tracts. ${ }^{96}$ Persistent AdV infection in children may elicit chronic neutrophilic inflammation within the airways, protracted bacterial bronchitis and bronchiectasis. ${ }^{97-99}$ HAdVs (particularly types $1-5,7,14$, and 21 ) have been associated with small airways dysfunction $^{96}$ and bronchiectasis in children ${ }^{94,98}$ and chronic obstructive pulmonary disease in adults. ${ }^{100,101}$ These various studies suggest that HAdV is not an innocent bystander in the lower airways, but may play a role in the pathogenesis of chronic suppurative endobronchial and lung disease.

\section{Keratoconjunctivitis}

Manifestations of ocular AdV infection include: epidemic KC (EKC), pharyngoconjunctival fever, and nonspecific conjunctivitis. ${ }^{49,102-106}$ The most common serotypes associated with EKC are AdV-8, -19 , and $-37,{ }^{49,103,105-112}$ but other serotypes (e.g. AdV-3, -4, -7, -11, and -14) can also cause conjunctivitis. $46,47,105,106,108,113,114$ Outbreaks of EKC can occur in hospitals or outpatient clinics, ${ }^{102,103,115}$ chronic care facilities, ${ }^{66,116}$ and closed settings. ${ }^{117}$ Nosocomial transmission has been noted in eye clinics or hospitals via environmental contamination (ophthalmic instruments, eyedrops)..$^{103,115,118}$ Rigorous sterilization of instruments and strict infection control were essential to curb epidemics. ${ }^{103,115}$ The recently described genotypes 53,54 , and 56 of species HAdV-D have been reported in association with outbreaks of EKC. ${ }^{119-124}$

\section{Gastrointestinal Manifestations}

AdV infections can cause GI symptoms even when the primary site of involvement is the respiratory tract (particularly in young children). $3,13,88,125$ Some serotypes (notably AdV-40 and -41) have an affinity for the GI tract, ${ }^{50,53,54,57}$ with predominant symptoms of gastroenteritis or diarrhea. ${ }^{126}$ Rare complications include hemorrhagic colitis, 2,27,127 hepatitis, ${ }^{27,128-131}$ cholecystitis, ${ }^{132}$ and pancreatitis. ${ }^{133,134}$

\section{Urinary Tract Involvement}

AdV may cause urinary tract infections (UTIs), ${ }^{135}$ particularly among hematopoietic stem cell transplant (HSCT) ${ }^{71,136-139}$ and solid organ transplant (SOT) recipients. ${ }^{140-143}$ Typical manifestations include dysuria, hematuria, hemorrhagic cystitis (HC), and renal allograft dysfunction. ${ }^{141,142,144,145}$ Most AdV UTIs (including HC) are self-limiting $43,71,140,144$ but fatal or dialysis-dependent renal failure, ${ }^{146-148}$ fatal dissemination, ${ }^{149,150}$ necrotizing tubulointerstitial nephritis, ${ }^{148,151}$ or obstructive uropathy ${ }^{151}$ have been described. Most common serotypes associated with HC include: AdV-11, -34, -35, -3, -7, and $-21.2,142,144,148$ The diagnosis may be confirmed by culture or polymerase chain reaction (PCR) in urine, or serology. ${ }^{2,137,142}$ Renal biopsy may demonstrate viral infection of tubular epithelial cells, with "smudge cells" and intranuclear inclusions. ${ }^{147,148} \mathrm{AdV}$ urethritis has also been described. ${ }^{152}$

\section{Disseminated Disease}

Disseminated AdV infections are rare among immunocompetent hosts, but dissemination occurs in 10 to $30 \%$ of HSCT recipients with AdV infection. ${ }^{2,25,26,38,153-155}$ Diagnosis is made by PCR in blood ${ }^{150}$ and/or detection (or recovery) of AdV from more than one site. Among HSCT recipients with symptomatic AdV disease, fatality rates range from 12 to 70\%. ${ }^{25,153,156-158}$ Case fatality rates for AdV pneumonia may exceed $50 \% .27,90$

\section{Rare Manifestations}

Rare manifestations of AdV infections include: encephalitis $^{159-163}$; meningitis ${ }^{162,164,165}$; myocarditis and cardiomyopathy $^{166,167}$;mononucleosis-like syndromes ${ }^{168}$; pulmonary dysplasia ${ }^{169}$; intestinal intussusception in children ${ }^{170}$; sudden infant death. ${ }^{171}$

\section{Specific Patient Populations at Risk}

\section{Adenovirus Infections in Immunocompetent Persons}

Epidemics of AdV respiratory infection may occur in healthy children (particularly $<4$ years old) $3,10-13,172$ or adults in closed settings (particularly the military). ${ }^{17,19-21,173}$ The vast majority of cases are self-limited; disseminated and fatal infections are rare in immunocompetent hosts. ${ }^{19,90}$

\section{Adenovirus Infections in Military Recruits}

AdV accounts for $>50 \%$ of FRI and pneumonia cases among unvaccinated military recruits, ${ }^{16,17,20,33,68,69,173}$ not only in the United States ${ }^{19,40,74}$ but globally ${ }^{44,75}$ Military recruits are especially vulnerable during basic training, owing to crowding and stresses. ${ }^{19}$ In a survey of eight military training sites in the United States from 2004 to 2009, > 21,000 cases of FRI or pneumonia were detected; AdV was implicated in 63.6\%; influenza, in only $6.6 \%{ }^{76}$ Peak illness rates occur during weeks 3 to 5 of training. ${ }^{20}$ In a prospective study of 271 new military recruits in training, 25\% developed an acute FRI due to AdV-4 over a 6-week period; all FRIs occurred among recruits with an initial AdV antibody titer of $<1: 4 .{ }^{69}$ Serum antibodies to AdV-4 were present in $34 \%$ at enrollment, and $97 \%$ by 6 weeks. ${ }^{69}$ Following completion of basic training, recruits are dispersed to secondary sites, paving the way for epidemic spread ${ }^{86}$ Historically, serotypes AdV-7 and -4 predominated as a cause of FRIs in the military in the United States. $16,17,40$ Beginning in 1971, all recruits in the United States military were vaccinated with live enteric-coated AdV-4 and -7 vaccines. ${ }^{174}$ Following this strategy, the incidence of AdV infections in the military setting plummeted. ${ }^{174}$ In 1995 , the sole manufacturer of the AdV vaccines ceased production; existing supplies were completely depleted by $1999 .{ }^{19}$ In 1996 , the last year AdV vaccines were given to recruits year round, AdV-21 was the most prevalent type, implicated in $58 \%$ of AdV infections; AdV-4 and -7 were each implicated in only $4 \% .{ }^{175}$ The lack of availability of vaccines led to re-emergence of epidemics of AdV infections in military facilities in the United States. ${ }^{19,20,40,74,176-178}$ Surveillance of U. S. recruits in training cited $>73,000 \mathrm{AdV}$ infections from 1999 to 2004; serotype 4 accounted for $>95 \%$ of AdV infections. ${ }^{20}$ In a large surveillance study of eight military recruit training centers in the United States from 2000 to 2011, AdV-4 was implicated in $80 \%$ of AdV infections; the remaining $20 \%$ comprised AdV- 14 , $-21,-3$, and $-7 .{ }^{175}$ In 2006 and 2007, a novel strain of AdV-14 
emerged as a cause of FRIs in recruits at a U. S. Air Force base, ${ }^{33}$ and became the predominant strain in the military.

Beginning in October 2011, after a 12-year hiatus, the administration of live nonattenuated oral vaccines against AdV-4 and -7 to U. S. military recruits was resumed. ${ }^{179}$ From 1996 to 2013, FRI surveillance was performed at eight military training centers in the United States. ${ }^{175}$ During the 2 years after reintroduction of the vaccine, AdV burden declined 100-fold (from 5.8 to 0.02 cases per 1,000 person weeks, $p<0.001) .{ }^{175}$ Although the percentage of type 14 increased following reintroduction of the vaccine, the mean annual number of AdV-14 infections decreased (from 610 in 2000 to 2011 to 44 in 2013). ${ }^{175}$ Continuing to vaccinate all incoming recruits will reduce cases among trainees, and may reduce transmission to other geographical locations and to civilians. ${ }^{175}$ Future surveillance studies will monitor AdV infection rates and pay attention to emergence of AdV types not targeted by the vaccines.

\section{Hematopoietic Stem Cell Transplant Recipients}

The incidence of AdV infections among HSCT recipients is highly variable (range, 3-47\%). 2,4,25-28,42,153-156,180-184 The incidence is much higher among allogeneic (range, 5-47\%) ${ }^{4}$ compared with autologous (range, 2.5-14\%) ${ }^{185-187}$ HSCT recipients. Higher rates of AdV infections reflect prospective studies with regular (often weekly) sampling of plasma for AdV DNA (by PCR). ${ }^{153,188}$ The incidence is 2 to 3.5 times higher in children $(>20 \%$ ) compared with $<10 \%$ in adults. ${ }^{38,181,182,189,190}$ Additional risk factors for AdV infections among HSCT recipients include: allogeneic $\mathrm{HSCT}^{4,38,182}$; graft versus host disease (GVHD) 2,25,27,28,153,154,156,182,191; severe T-cell depletion ${ }^{28,38,191}$; human leukocyte antigen (HLA) mismatch. ${ }^{38,192}$ Infection can reflect primary infection (e.g., community or nosocomial acquisition) ${ }^{73}$ or reactivation of latent infection. ${ }^{70,73}$

AdV in HSCT recipients is usually detected within 100 days of transplant. ${ }^{38,193}$ The disease is usually localized (e.g., urinary tract, gastroenteritis, upper or lower respiratory tract) but dissemination occurs in 10 to $30 \%$ of cases. ${ }^{28,38,181,189}$ In this context, mortality rates are high. ${ }^{38}$ Among 76 adult HSCT recipients with symptomatic AdV infections, mortality rate was $26 \%{ }^{182}$ Mortality rates were higher among patients with pneumonia (73\%) and disseminated disease (61\%). ${ }^{182}$ Severe lymphopenia, ${ }^{2,38}$ severe GVHD, ${ }^{28,182}$ isolation from more than one site, ${ }^{38}$ and high AdV viral loads in plasma ${ }^{194,195}$ correlate with higher mortality. In one study of 123 consecutive pediatric allogeneic HSCT recipients, $12.3 \%$ developed symptomatic AdV infections. ${ }^{183}$ Overall survival was much worse in patients with AdV infections (15.4\%) compared with noninfected subjects (50\%; $p<0.03$ ). In multivariate analysis, the most important risk factor for mortality was AdV infection (hazard ratio, 3.15; $p<0.001) .{ }^{183}$ However, prognosis may be good, particularly when the viral load is low. A retrospective study in pediatric HSCT recipients detected AdV in blood (by PCR) in 11/26 (42\%); viremia cleared in 7 (63\%) without antiviral therapy. ${ }^{43}$ In another study of 116 adult HSCT recipients who had weekly screening for AdV in blood by PCR, 14 (12.1\%) developed AdV viremia. ${ }^{193}$ Only five were treated with cidofovir (CDV); only one died as a result of AdV infection. In another study of pediatric HSCT recipients, weekly sampling of plasma PCR identified 57 patients with AdV infections; 8 (14\%) patients had disseminated disease. All 57 patients were treated with intravenous CDV; clinical and microbiological cure was achieved in 56 (98\%). One patient died of AdV pneumonia. ${ }^{188}$ Quantification of AdV DNA load by real-time PCR in plasma of HSCT recipients may identify patients at high risk for dissemination ${ }^{189,194}$ or assess response to therapy. ${ }^{189,194}$ However, indications for, and duration of therapy, with CDV are controversial.

\section{Solid Organ Transplant Recipients}

The incidence of AdV infections among SOT recipients is 5 to $22 \%$, usually within the first 6 months posttransplantation. 2,4,38,156,196,197 AdV infections have been noted in liver, ${ }^{198,199}$ renal, ${ }^{140,142,146,200-202}$ heart, ${ }^{196,203,204}$ intestinal, ${ }^{205,206}$ and lung ${ }^{207-209}$ transplant recipients. Among SOT recipients, risk factors for AdV include: pediatric age $e^{4,38,198}$; donor-positive/recipient-negative AdV status ${ }^{38}$; receipt of antilymphocyte antibodies. ${ }^{38}$ In a prospective study, AdV viremia (by PCR) was detected within 12 months of transplant in 19/263 (7.3\%) SOT recipients including: liver, 10/121 (8.3\%); kidney, 6/92 (6.5\%); heart, 3/45 (6.7\%). ${ }^{196}$ At the time of viremia, 11 (58\%) were asymptomatic. All recovered spontaneously without sequela. In a retrospective review of 484 pediatric liver transplant recipients, $49(10 \%)$ developed AdV infections; 9 died of invasive AdV infection. ${ }^{198}$ In another retrospective review of 191 adult liver transplant recipients, 11 (5.8\%) had AdV infection, and 2 AdV-associated deaths were documented. ${ }^{199}$ Clinical manifestations of AdV infection are protean, but the primary site of disease in SOT recipients is often related to the transplanted organ. ${ }^{38,210}$ In liver transplant recipients, AdV typically causes hepatitis, jaundice, and hepatomegaly. ${ }^{38}$ In renal transplant patients, HC is the principal symptom; further, AdV may target the renal allograft, leading to graft failure. $^{142,146,200}$ In pediatric heart transplant recipients, the presence of AdV in posttransplant endomyocardial biopsies increased the risk for graft loss and posttransplant coronary artery disease. ${ }^{211-213}$ In a cohort of 383 lung transplant recipients (LTRs), only $4 \mathrm{AdV}$ infections were identified; incidence was 3/40 (8\%) among pediatric LTR and 1/268 (0.4\%) among adult LTR. ${ }^{207}$ However, all four developed severe hemorrhagic, necrotizing AdV pneumonia; all died within 45 days of transplant. In another study of 19 pediatric LTR, 8 developed AdV, resulting in 2 early deaths, as well as late graft loss and obliterative bronchiolitis. ${ }^{200} \mathrm{~A}$ case of fatal AdV pneumonia in an adult LTR 4 years posttransplant was described. ${ }^{214}$ Although AdV can cause fatal infections in SOT recipients, indications for treatment with CDV for mild infections have not been established. AdV viremia may be asymptomatic, and may clear spontaneously. ${ }^{196}$ Routine PCR surveillance is not recommended in adult SOT recipients. Further, treatment (with CDV) should be reserved for symptomatic patients or those with pneumonia or disseminated infection. 


\section{Human Immunodeficiency Virus Infection}

AdV infections occur in 12 to $28 \%$ of human immunodeficiency virus (HIV)-infected patients. ${ }^{215,216}$ In one prospective study of $63 \mathrm{HIV}+$ patients, 18 (28\%) developed AdV infections within 1 year $\left(17 \%\right.$ if $\mathrm{CD}_{4}$ count was $>200 / \mathrm{mm}^{3}$ vs. $38 \%$ if the $\mathrm{CD}_{4}$ count was $\left.<200 / \mathrm{mm}^{3}\right) .{ }^{216}$ In Nigeria, $39 \%$ of 184 HIV-infected patients had serological evidence for AdV infection. ${ }^{217}$ The GI tract is involved in $>90 \%$, but most patients are asymptomatic or have mild symptoms (e.g., diarrhea). ${ }^{216}$ UTIs occur in up to $20 \%$ of AIDS patients, ${ }^{218}$ but HC is rare. ${ }^{38}$ Serotype D is associated with GI infection whereas UTIs are usually caused by serotypes B or D. ${ }^{216} \mathrm{AdV}$ (particularly serotypes 1 to 3 ) may cause fatal cases in HIV-infected patients. ${ }^{38,197}$ Since the availability of highly active antiretroviral therapy, AdV disease is uncommon in HIV/AIDS patients until immune system deterioration occurs. ${ }^{38}$

\section{Congenital Immunodeficiency Syndromes}

AdV infection may complicate congenital immunodeficiency disorders such as severe combined immunodeficiency syndrome, common variable immunodeficiency, agammaglobulinemia, immunoglobulin A deficiency, and others. ${ }^{38,64,197,219}$ In patients with severe immunodeficiency, $\mathrm{AdV}$ tends to cause severe and recurrent pulmonary infections, disseminated disease, and even death. ${ }^{38}$

\section{Importance of Serotypes}

Globally, serotypes 1 to 5, 7, 21, and 41 are most commonly associated with human disease ( $\mathbf{- T a b l e} \mathbf{1}$ ). Different serotypes display different tissue tropisms and clinical manifestations of infection. ${ }^{2,26,31,33}$ Among children, the most common AdV serotypes associated with RTI are types 1 to 7 and an intertypic recombinant H11F14 designated as genotype $55 .{ }^{31,220}$ In adults, serotypes most often implicated in FRI include: AdV-1 to 7, -21, and $-14 .{ }^{10,16-18,24,33,40,41,75,221,222}$ AdV-55 was implicated in outbreaks of FRI in China, ${ }^{81}$ Singapore, ${ }^{44}$ the Middle East, ${ }^{223}$ United States, ${ }^{21}$ and South America. ${ }^{224}$ AdV-11 may cause UTIs or $\mathrm{HC}$ in children or transplant recipients. ${ }^{33,38}$ Other serotypes associated with HC include: AdV-7, $-33,-34$, and $-35 .{ }^{33,225}$
AdV-8, - 19, and -37 are frequent causative agents of KC. $^{31,105,226}$ Gastroenteritis is most frequently associated with infection by enteric AdV-40 and $-41,{ }^{9,227}$ but has also been reported in association with AdV- $12,-18$, and $-31,{ }^{9}$ and AdV$52^{32}$ infection. AdV-5,-31, -34,-35, and -39 have been implicated in infections in immunocompromised patients ${ }^{43,51,180,220,228}$ (particularly HSCT ${ }^{2,43,128,229,230}$ or SOT ${ }^{142,231}$ recipients). Hepatitis has been reported associated with infection by serotypes 1 to 3,5 , and $7 .^{38,225}$

\section{Molecular Characterization of Adenovirus}

Different genome types within serotypes have been identified by restriction enzyme analysis, ${ }^{39,40,232}$ multiplex PCR techniques targeting fiber genes or hexon genes ${ }^{233}$ or sequencing of the fiber genes ${ }^{29,234}$ and hexon genes. ${ }^{29,31,235}$ The widely used genome typing system was proposed and modified by $\mathrm{Li}$ et al. ${ }^{12,236}$ The prototype AdV strain is designated "p"; other genome types within the serotype are designated "a" through " $k$ " based on their distinct BamHI digestion profiles. Genome types may be further distinguished by restriction pattern with additional selected enzymes (e.g., AdV-7p, AdV-7p1, etc.). ${ }^{12,40,80}$ This system has been used to correlate intraserotypic genetic variability with geographic distribution and pathogenic potential. ${ }^{40}$

\section{Whole Genome Sequencing and Designation of Viruses Described by Bioinformatics Analysis of Complete Genomic Sequences}

Rapidly advancing sequencing technologies at affordable costs have allowed relatively easy access to complete genomic sequence data for human AdV strains expanding the information on the genetic makeup of several viruses of medical importance and contributing to a better understanding of AdV evolution. ${ }^{35,237-240}$

Novel genomes representing cases of intertypic recombination or viruses with truly novel hexon, penton base or fiber genes have been under consideration as candidate new types and designated with numbers consecutive to the original set

Table 1 Adenovirus serotype according to geographic region

\begin{tabular}{|c|c|c|c|c|c|c|c|}
\hline Country & 1 & 2 & 3 & 4 & 7 & 21 & 41 \\
\hline United States (2004-2007) (civilians) $^{161}$ & $17.7 \%$ & $24.3 \%$ & $34.6 \%$ & $4.8 \%$ & $3.0 \%$ & $2.0 \%$ & $1.7 \%$ \\
\hline United States (2004-2007) (military) ${ }^{161}$ & NA & NA & $2.6 \%$ & $92.8 \%$ & NA & $2.4 \%$ & NA \\
\hline Toronto $(2007-2008)^{5}$ & $18 \%$ & $26 \%$ & $46 \%$ & $4.8 \%$ & NA & $5.5 \%$ & NA \\
\hline Korea $(1991-2007)^{31}$ & $9.2 \%$ & $11.2 \%$ & $37 \%$ & $3.9 \%$ & $23.3 \%$ & NA & NA \\
\hline${\text { Taiwan }(1981-1989)^{11}}^{11}$ & NA & $6 \%$ & $68 \%$ & $0 \%$ & $3 \%$ & NA & NA \\
\hline Taiwan $(2000)^{11}$ & NA & $6 \%$ & $36 \%$ & $28 \%$ & $21 \%$ & NA & NA \\
\hline Taiwan $(2001)^{11}$ & $\mathrm{NA}$ & $15 \%$ & $2 \%$ & $52 \%$ & $1 \%$ & NA & NA \\
\hline Taiwan $(2004-2005)^{3}$ & $4.1 \%$ & $6.4 \%$ & $87.2 \%$ & $0.6 \%$ & NA & NA & NA \\
\hline United Kingdom (1982-1996) 248 & $12.1 \%$ & $18.6 \%$ & $14.9 \%$ & NA & NA & NA & $10.9 \%$ \\
\hline
\end{tabular}

Abbreviation: NA, not applicable.

Source: Reproduced with permission from Lynch et al. ${ }^{1}$ 
of 51 used to designate HAdV serotypes. The criteria for designation remain a matter of active debate. ${ }^{241}$

\section{Global Epidemiology}

The predominant serotypes detected in association with disease differ among different countries or regions, and change over time. $3,12,31,40,86,242-245$ Transmission of novel strains between countries or across continents and replacement of dominant serotypes by new strains may occur. ${ }^{33,246}$

Serotypes 1 to 7 account for $>80 \%$ of AdV infections in infants and children. ${ }^{31,247}$ The most common serotypes reported in the United States, ${ }^{161}$ Canada, ${ }^{5}$ the United Kingdom, 248 Taiwan, ${ }^{11}$ and South Korea ${ }^{31}$ are displayed in - Table 1. Striking differences in distribution of serotypes have been noted in civilian and military populations ${ }^{161}$ (-Table $\mathbf{1}$ ).

In South America, AdV-7 has been a predominant strain associated with RTI requiring hospitalization in many countries. ${ }^{10,224}$ In Brazil, AdV-7 was the predominant serotype for decades, but an outbreak of AdV-3 occurred in 2000. ${ }^{10}$ In Asia, AdV-3 and -7 have been the predominant serotypes associated with RTI in children. ${ }^{3,11-13,249}$

Documented changes in relative prevalence of serotypes and genomic variants among geographic regions underscore the potential for new strains to emerge and replace existing strains. $^{10-12,40,65,244,246,250-252}$ For interested readers, we discussed the epidemiology and temporal changes in circulating genomic variants globally in greater detail in a review in 2011. ${ }^{1}$

\section{Epidemiology and Characteristics of Specific Serotypes}

Given the large number of AdV serotypes, a discussion of each serotype is beyond the scope of this review. However, we will discuss a few of the commonly detected serotypes (e.g., AdV-1, -2, -3, -4, -7, and -21), additional serotypes associated with specific clinical syndromes (e.g., AdV-8, $-37,-40,-41$, and -55 ) and the recent emergence of AdV-14 in the United States.

\section{Adenovirus Serotypes 1 and 2}

Serotypes AdV-1 and -2 (both species C) are common causes of acute FRI worldwide, but appear to be less virulent than AdV-7 $7^{11,224,246}$ or $-3^{88,224}$ However, a nosocomial outbreak of severe pneumonia in immunocompetent hosts due to AdV-1 was recently described in France. ${ }^{253}$ The prevalence of AdV-1 and -2 varies among different geographic regions and populations. In the United States (2004-2006), AdV-1 and -2 accounted for 17.6 and $24.3 \%$ of AdV clinical respiratory isolates among civilians (children or adults), respectively, but only 0.4 and $0.4 \%$ among military recruits. ${ }^{161}$ The prevalence of these serotypes at other sites is variable: that is, Toronto, Canada (2007-2008), AdV-1 (18\%); AdV-2 (26\%) ${ }^{5}$; United Kingdom (1982-1996), AdV-1 (12.1\%); AdV-2 (18.6\%) ${ }^{248}$; Buenos Aires (1984-1988); AdV-1 (10\%); AdV-2 (20\%) ${ }^{246}$; Seoul, Korea (1990-98); AdV-1 (9.2\%); AdV-2 (11.2\%). ${ }^{88}$

\section{Adenovirus Serotype 3}

Globally, AdV-3 is among the most common serotypes implicated in AdV infections in children and adults. ${ }^{3,84,161,251}$ AdV accounted for $13 \%$ of AdV respiratory isolates reported to the World Health Organization from 1967 to $1976^{84}$ and remains a cause of endemic and epidemic infections ${ }^{3,5,19,161,248}$ (-Table 1). In the United States and southern Ontario from 2004 to 2006, AdV-3 accounted for 34.6\% of AdV RTI in civilians but only $2.6 \%$ among military trainees. ${ }^{161}$ The prevalence of AdV3 at other sites is variable: that is, Toronto, Canada (2007-2008), $(46 \%)^{5}$; United Kingdom (1982-1996), (14.9\%) 248 ; Seoul, Korea (1990-1998), (15\%) ${ }^{88}$; Seoul, Korea (1991-2007), (37.0\%). ${ }^{31}$ In Taiwan, AdV-3 was the predominant serotype in 1981-1989 (68\%) and $1990-1998$ (44\%) but decreased to $2 \%$ of respiratory isolates in 2001 (largely replaced by AdV-4 and $-7^{11}$ ). During an outbreak of respiratory AdV infections in children from November 2004 to February 2005 in Taiwan, AdV-3 was implicated in $87.5 \%$ of the cases. ${ }^{3}$ AdV-3 may cause fatal pneumonias in immunocompetent children ${ }^{249,254}$ and adults. ${ }^{65}$ AdV-3 and a recombinant strain of AdV-3/7 were responsible for an outbreak of FRIs (including two fatalities) in children in Portugal in $2004 .^{254}$

\section{Adenovirus Serotype 4}

AdV-4 is a cause of sporadic infections in civilians ${ }^{5}$ and has been implicated in epidemic outbreaks of FRI or pneumonia in civilian $^{11,255}$ and military ${ }^{18,20,74,177}$ populations. In civilian populations, AdV-4 was implicated in $4.8 \%$ of AdV RTI in the United States (2004-2006) ${ }^{161} ; 1 \%$ in Toronto, Canada (2007-2008) $3.9 \%$ (pediatric isolates) in South Korea (1991-1997). ${ }^{31}$ In Taiwan, AdV-4 accounted for $29 \%$ of pediatric respiratory isolates from 1981-2001, and became the predominant serotype (52\%) in $2001 .{ }^{11}$ Until recently, AdV-4 was the most common serotype associated with FRI in military recruits in the United States. ${ }^{18,80,177,256}$ The strategy of vaccinating all military recruits against AdV-4 and -7 beginning in $1971^{174,257}$ eliminated both serotypes as causes of epidemic of FRI in the military for more than two decades. ${ }^{80}$ After the vaccine was depleted, an outbreak of AdV-4 occurred at an Army basic training site in $1997 .{ }^{74}$ Over the next several years, AdV-4 spread to multiple secondary sites. $^{20}$ From 1999 to 2004, AdV-4 accounted for $>95 \%$ of AdV FRI among military recruits in the United States. ${ }^{20}$ By 2006 to 2007 the emerging AdV-14 largely replaced AdV-4 as a cause of AdV FRI among military recruits in the United States. ${ }^{33}$ After a 12-year interruption in vaccination the original vaccine formulation was reintroduced in October of 2011 resulting in a dramatic decline in the rates of AdV-associated febrile illness among recruits in training. ${ }^{175}$

\section{Adenovirus Serotype 7}

Globally, AdV-7 was the third most common serotype reported to the World Health Organization from 1967 through 1976, following AdV-1 and $-2^{84}$ and remains one of the leading serotypes detected in association with disease globally. ${ }^{31,40,258} \mathrm{AdV}-7$ infections manifest as FRI, 
pharyngoconjunctival fever, bronchitis, necrotizing bronchiolitis, or pneumonia. ${ }^{40,224,259}$ AdV-7 appears to be more virulent than other serotypes. ${ }^{11,88,224,242,249,260-262}$ Fatal pneumonias may occur in immunocompetent children $^{6,224,250,263,264}$ and adults. ${ }^{23,265}$

Epidemic AdV-7 infections have been reported in the United States, ${ }^{6,264,266}$ Canada, $^{263}$ Latin America, ${ }^{224,267}$ Australia, ${ }^{268}$ Israel, ${ }^{243}$ Korea, ${ }^{75,88}$ Japan, ${ }^{242,259}$ China, ${ }^{12,262}$ the Philippines, ${ }^{261}$ and globally. ${ }^{161,243}$ Outbreaks typically occur in closed settings (e.g., military barracks ${ }^{18,39}$; chronic care facilities $^{80}$; hospitals $s^{6,78,269,270}$ ). In the late 1960 s, AdV-7 and -4 accounted for most cases of FRI among military recruits in the United States. ${ }^{80,256}$ Following routine vaccination of military recruits in the United States beginning in $1971,{ }^{174,257}$ no epidemics of FRI were attributed to AdV-7 or -4 from 1984 through $1994 .{ }^{80}$ However, in 1997 (after the vaccine supply was depleted), an epidemic ( $>500$ cases) of AdV FRI in a U. S. Navy training site was attributed to serotypes AdV-7 (70\%) and AdV-3 (24\%), respectively. ${ }^{19}$ Since 2007 , AdV-7 has largely disappeared as a cause of FRI in U. S. military settings (possibly replaced by AdV-14). ${ }^{33}$

The prevalence of AdV-7 varies according to geographic regions and over time, and depends on strain genome type, herd immunity in the region, and epidemiological settings. ${ }^{6,80,161,264}$ In the United States from 2004 to 2006, AdV-7 accounted for only 5/581 (0.9\%) of clinical AdV respiratory isolates in military facilities and 48/1,653 (2.9\%) isolates in civilian settings. ${ }^{161}$ By contrast, AdV-7 was a prominent cause of FRI in South America in the

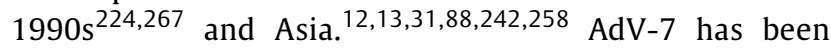
recently reported in association with severe disease in several provinces of China. ${ }^{262,265,271}$ AdV-7 was the leading cause of death due to AdV pneumonia in South America in the 1980 s and 1990 s. $^{224,267}$ In a study of 165 AdV RTIs in children in Argentina and Uruguay, AdV-7 accounted for $62.2 \%$ of isolates and was responsible for 17 of 18 fatalities. $^{224}$ The prevalence of AdV-7 as a cause of AdV FRI is Asia is variable, ranging from $<1242$ to $>60 \% .{ }^{75}$ In Seoul, Korea from 1990 to 1998, AdV-7 accounted for 41\% of RTI (followed by AdV-3 [15\%] and AdV-2 [15\%]). ${ }^{88}$ From 1991 to 2007 in Seoul, AdV-7 accounted for $23.3 \%$ of pediatric respiratory AdV isolates, second only to AdV-3 (37.0\%) (-Table 1). ${ }^{31}$ In a survey of 200 military recruits in South Korea in 2006, 122 recruits (61\%) developed AdV infections; all 122 isolates were AdV-7. ${ }^{75}$ In Taiwan, AdV-7 emerged as the predominant serotype (45\%) in 1999 to 2000, but fell drastically to $1 \%$ in 2001 (replaced by AdV-4). ${ }^{11}$ In Beijing, China, AdV-7 and -3 were the most common serotypes causing pneumonia from 1958 to $1990 .^{12}$

At least 27 genome types of AdV-7 have been identified by restriction enzyme fragment analysis ${ }^{80}$; shifts or replacement of predominant genome types may occur. ${ }^{40,161,243,244}$ In some cases, new genomic variants exhibit an apparent heightened virulence or transmissibility compared with earlier strains. For interested readers, the epidemiology, global shifts, and changing genotypes of AdV-7 were discussed in detail in our previous review. ${ }^{1}$

\section{Adenovirus Serotype 8}

AdV-8 accounts for $<1 \%$ of AdV infections, $5,31,88,161$ but is a common cause of EKC. ${ }^{88,105,107,111,116,272,273}$ In four studies in Asia and the Middle East, AdV-8 accounted for 64 to $79 \%$ of EKC due to AdV. ${ }^{105,106,109,117}$ In a neonatal intensive care unit in Turkey, cases of conjunctivitis due to AdV-8 were linked to a contaminated eyelid speculum. ${ }^{272}$

\section{Adenovirus Serotype 11}

AdV-11 is relatively uncommon, but may cause hemorrhagic conjunctivitis $^{45-47,81}$ and FRI (including pneumonia) in immunocompetent patients and $\mathrm{HC}$ in immunocompromised patients. $^{21,81}$ In the United States from 2004 to 2006, AdV-11 accounted for $<1 \%$ of AdV RTI in military recruits and civilians $^{161}$; in Toronto, Canada, AdV-11 was not detected among 96 clinical respiratory AdV isolates ( - Table $\mathbf{1}$ ). AdV-11 comprised $3.4 \%$ of 741 pediatric respiratory isolates from Korea from 1991 to $2007 .^{31}$ Outbreaks of AdV-11 FRIs were described in South America, ${ }^{224}$ United States, ${ }^{21,274}$ Asia, ${ }^{44,81}$ the Middle East, ${ }^{223}$ and globally. AdV-11 may cause UTI, including HC, in organ transplant recipients (particularly children). 2,71,139,275

\section{Adenovirus Serotype 14}

AdV-14 was first isolated in the Netherlands in 1955 during an outbreak of acute respiratory disease (ARD) among military recruits. ${ }^{33}$ Subsequent outbreaks of ARD were described in Great Britain in 1955, ${ }^{276}$ Uzbekistan in $1962,{ }^{33}$ and Czechoslovakia in $1963 .{ }^{33}$ Apart from sporadic cases in the Netherlands in the early 1970s, no cases of AdV-14 infections were reported globally between the 1960s and 2004. ${ }^{13,33}$ AdV-14 had never been identified in North America before 2006. ${ }^{41}$ Beginning in March 2006, outbreaks of FRI due to AdV-14 (several hundred cases) were noted in several military bases in the United States ${ }^{68,86,274,277}$ and among health care workers. ${ }^{68}$ By 2007, outbreaks in civilian populations were documented in at least 15 states. ${ }^{24,33,221,222,278}$ The severity of FRIs was variable, but fatal pneumonias were reported. ${ }^{24,33,68,221,278}$ By 2007, AdV-14 had replaced AdV-4 as the dominant serotype on U. S. military bases. ${ }^{41,274}$ Analysis of 99 isolates recovered from patients (military and civilian) with AdV FRI between December 2003 and June 2009 from different geographic locations confirmed that all isolates were identical. ${ }^{33}$ These isolates represented a new genomic type designated AdV-14p1 (formerly known as 14a). ${ }^{33}$ The complete genetic sequence of AdV-14p1 indicates a close relationship to AdV-11a, suggesting recombination between AdV-14 and -11 strains. ${ }^{41}$ AdV-14p1 was implicated in outbreaks of severe pneumonias in the United States ${ }^{33}$ and Ireland. ${ }^{279}$ AdV-14p1 has an increased potential for high attack rates and rates of transmission, owing to the lack of herd immunity. ${ }^{41}$

\section{Adenovirus Serotype 21}

AdV-21 was associated with epidemics of FRIs in military recruits in the Netherlands in the $1960 \mathrm{~s},{ }^{280}$ but only sporadic 
cases were reported over the next two decades. ${ }^{281}$ In 1984 and 1985, outbreaks of AdV-21 infections in children in the Netherlands and Germany were published. ${ }^{281}$ AdV-21 has been associated with pharyngitis and conjunctivitis ${ }^{282}$ and FRI $^{228}$ but is uncommon. ${ }^{31}$ In the United States from 2004 to 2006, AdV-21 accounted for 2.0 and $2.4 \%$ of AdV RTI in civilians and military recruits, respectively. ${ }^{161}$ In Toronto, Canada (20072008), AdV-21 accounted for 5.5\% of clinical respiratory AdV isolates. By contrast, AdV-21 was never isolated in 741 pediatric respiratory isolates from Korea from 1991 to $2007 .{ }^{31}$ Interestingly, Adv-21 may be less transmissible than other AdV serotypes. $^{283}$ However, a highly virulent strain of AdV-21 was associated with severe pneumonia cases in Germany ${ }^{34}$ and neurological ${ }^{284}$ and cardiac $^{285}$ manifestations in Malaysia. Similar strains were found to circulate in the United States over the last 3 decades $^{39}$ with no apparent association with severe disease among the infected young adults.

\section{Adenovirus Serotype 31}

AdV-31 may cause gastroenteritis in healthy children, and has been associated with severe (sometimes) fatal infections in HSCT recipients. ${ }^{28,157,286-288}$ Nosocomial transmission (seven cases) in a pediatric SCT unit was described. ${ }^{288}$

\section{Adenovirus Serotype 37}

AdV-37 accounts for $<1 \%$ of AdV infections, ${ }^{5,31,88,161}$ but may cause EKC. ${ }^{88,103,105-109}$

\section{Adenovirus of Species F (Serotypes $\mathbf{4 0}$ and 41)}

AdV of species F (serotypes 40 and 41 ) typically cause gastroenteritis and diarrheal illness in children. ${ }^{50-61}$ Fatalities may occur as a result of dehydration in infants. ${ }^{50,51}$ In immunocompromised hosts, fatal dissemination may occur. ${ }^{73,289}$ Epidemics have been cited in schools ${ }^{56}$ and hospitals. ${ }^{73}$ Endogenous reactivation originating from AdV persistent in mucosal lymphoid cells may occur. ${ }^{70}$ Nosocomial transmission may occur due to high AdV levels in feces. ${ }^{73}$ Shedding of these viruses may be prolonged in immunosuppressed patients. ${ }^{73}$

\section{Adenovirus Genotype 55}

Infections due to AdV-55 of species B are rare, but this virus has been implicated in outbreaks of severe pneumonia and acute respiratory distress syndrome in China since 2006. ${ }^{89,91,290,291}$ This type is an intertypic recombinant with an AdV-11-like hexon gene and an AdV-14-like fiber gene. ${ }^{240}$ Several reports describing cases of respiratory infection by this unique AdV under other designations (AdV-11, $14-11$ or genome type $11 \mathrm{a}$, depending on the typing approach) can be found in the literature. ${ }^{44,292-294}$

\section{Diagnosis of Adenovirus Infection}

AdV can be detected in affected sites (e.g., nasopharyngeal aspirates, swabs, washings, bronchoalveolar lavage, urine, stool, blood) by direct or indirect immunofluorescence, conventional or shell vial cultures, or PCR. ${ }^{31}$ Viral cultures by conventional techniques are the gold standard, but could be insensitive for certain samples (e.g., blood) and may take up to 21 days to develop the cytopathic effect. ${ }^{2,31}$ Biopsy of involved tissues may reveal AdV nuclear inclusions ${ }^{2}$; immunohistochemical stains may identify the AdV hexon antigen in tissue. ${ }^{146}$ PCR of AdV DNA in plasma, urine, or other clinical specimens is currently the most frequently used approach to establish the diagnosis, 2,194 and is highly sensitive for disseminated disease. ${ }^{295,296}$ Quantification of the viral load using real-time PCR is a useful marker to assess response to therapy. ${ }^{189,295}$ Among transplant recipients, serial PCR assays of blood and stool weekly may detect AdV disease before the onset of symptoms, and facilitate early "preemptive" therapy. ${ }^{26,153,188,196}$ In one study of 138 pediatric allogeneic SCT recipients, AdV was detected in stool samples at median of 11 days before AdV viremia. ${ }^{297}$ The role of routine surveillance is controversial although it has been increasingly used in high-risk patients (particularly HSCT recipients ${ }^{2}$ ). Quantitative viral loads may not correlate with clinical presentation or disease severity. ${ }^{43}$

Molecular typing is not routinely performed on AdV-positive clinical specimens in clinical diagnostic laboratories but has been the focus of several recently reported studies investigating the epidemiology of AdV-associated disease. Serological tests may be useful in epidemiological investigations, but are of limited practical value in individual patients. ${ }^{38}$ Determination of serotype by seroneutralization with reference sera is laborious and time-consuming and currently only performed at a few reference public health laboratories around the world. PCR-based techniques targeting the fiber genes ${ }^{233}$ or hypervariable regions of the hexon ${ }^{235,298}$ and/or sequencing of hexon genes allow definitive identification of the type/species. ${ }^{29,31}$ Molecular typing by PCR amplification and sequencing of both hexon and fiber genes has proved to be extremely valuable for the identification of intertypic recombinants. ${ }^{299,300}$

\section{Therapy}

No antiviral drug has been approved to treat AdV. ${ }^{38}$ Prospective randomized controlled trials are lacking. ${ }^{14} \mathrm{CDV}$, a cytosine nucleotide analogue that inhibits DNA polymerase, has the greatest in vitro activity against AdV among currently available antiviral agents ${ }^{301-303}$ and is the preferred therapeutic agent. ${ }^{2}$ CDV is available only intravenously. ${ }^{2}$ Regimens (dosing, frequency, and duration) are variable. Standard doses include $5 \mathrm{mg} / \mathrm{kg}$ every 1 to 2 weeks $^{38,188}$ or $1 \mathrm{mg} / \mathrm{kg}$ twice weekly. ${ }^{38,158,188}$ Duration of therapy is variable (weeks to months) and depends upon clinical response and persistence or eradication of AdV. ${ }^{158,188}$ CDV is generally well tolerated, ${ }^{153,188,304}$ but adverse effects include nephrotoxicity, myelosuppression, and uveitis. ${ }^{2,38}$ Hydration and probenecid may minimize nephrotoxicity. 2,143,153,201,209 Careful monitoring of renal function (serum creatinine, proteinuria) is critical. Hexadecyloxy propyl-CDV or brincidofovir (CMX001), an orally active lipophilic form of CDV, has potent activity against AdV in vitro ${ }^{305}$ and in animal models, ${ }^{306,307}$ with anecdotal successes in small clinical 
series. $^{308,309}$ Compared with CDV, CMX001 appears be less nephrotoxic. ${ }^{310}$ An open-label phase 3 trial to assess safety and efficacy of CMX001 for treating AdV infections in immunosuppressed patients is in progress (Clinical Trials.gov identifier: NCT02087306).

Numerous nonrandomized studies in HSCT and SOT recipients documented favorable responses to CDV. ${ }^{25,26,28,153,158,188,192,209,231,311-317}$ Three studies of allogeneic HSCT recipients with AdV infections cited improvement with CDV in $20 / 29(69 \%),{ }^{311} 10 / 14(77 \%),{ }^{318}$ and $8 / 10(80 \%)$ patients, respectively. ${ }^{192}$ However, given the lack of controlled trials, indications for, and efficacy of CDV remain controversial. ${ }^{27}$ Interpretation of these studies is confounded by heterogeneous patient populations, differing extent and sites of disease, and degree of immunosuppression or immune reconstitution. ${ }^{38}$ Intravenous immunoglobulin has been used (together with CDV), but data are insufficient to assess efficacy. ${ }^{25,316}$

Immune reconstitution plays a critical role in controlling AdV infection. ${ }^{38}$ Increases in lymphocyte counts or $\mathrm{CD}_{4}$ counts were associated with clearance of AdV infection ${ }^{319,320}$ and improved survival. $^{320,321}$ Serotypic-specific neutralizing antibodies correlate with clearance of AdV. ${ }^{38,320}$ Reduction of immunosuppression, ${ }^{146,153}$ immune reconstitution of HSCT recipients, ${ }^{25,38}$ or donor leukocyte infusions ${ }^{28}$ may have adjunctive roles to treat serious or recalcitrant AdV infections. T cells are important to eradicate AdV. Adoptive transfer of AdV antigen-specific T cells may reconstitute immunity against $A d V .^{322,323}$ In a recent clinical trial of HSCT recipients with AdV disease refractory to therapy, ex vivo adoptive T-cell transfer with predominantly TH1 phenotype was highly effective in clearing viremia and markedly reduced mortality. 324

Importantly, not all patients with AdV infections or viremia require treatment. ${ }^{2,14,43,201}$ High-mortality rates in retrospective studies in part reflect that virtually all patients had symptomatic AdV infections. Prospective studies in $\mathrm{SOT}^{196}$ or $\mathrm{HSCT}^{43}$ recipients using plasma PCR at regular intervals noted that up to $58 \%$ were asymptomatic at the time of viremia, and spontaneous resolution without sequela was common. In a cohort of SOT recipients with AdV viremia, all 19 recovered spontaneously without sequela. ${ }^{196}$ Similarly, in a cohort of 26 pediatric HSCT recipients, 11 (42\%) developed AdV viremia that cleared without therapy in 7 (64\%). ${ }^{43}$ Two children died as a result of AdV infections. Antiviral treatment should be considered for the following indications: disseminated ( $\geq 2$ sites) disease; pneumonia; high viral loads in blood; virulence or tropism of the viral strain; persistent severe lymphopenia or immune deficits. Further, "preemptive" therapy may have a role in viremic but asymptomatic organ transplant recipients at high risk for dissemination. Prospective, randomized trials are needed to elucidate indications for therapy in both symptomatic and asymptomatic patients with AdV infections.

\section{Vaccines}

Oral vaccines against AdV types 4 and 7 developed for the U.S. military in $1971^{20}$ were depleted by $1999 .{ }^{20}$ Produced by a new manufacturer, and after a new round of clinical trials ${ }^{179}$ the same live nonattenuated vaccine formulation for AdV-4 and -7 was successfully reintroduced for military use in the United States in October 2011. ${ }^{39}$ Importantly, antibodies to AdV-4 and -7 may cross protect against other serotypes (e.g., AdV-3 and -14). ${ }^{86,274,325}$

\section{References}

1 Lynch JP III, Fishbein M, Echavarria M. Adenovirus. Semin Respir Crit Care Med 2011;32(4):494-511

2 Ison MG. Adenovirus infections in transplant recipients. Clin Infect Dis 2006;43(3):331-339

3 Chang SY, Lee CN, Lin PH, et al. A community-derived outbreak of adenovirus type 3 in children in Taiwan between 2004 and 2005. J Med Virol 2008;80(1):102-112

4 Sandkovsky U, Vargas L, Florescu DF. Adenovirus: current epidemiology and emerging approaches to prevention and treatment. Curr Infect Dis Rep 2014;16(8):416

5 Yeung R, Eshaghi A, Lombos E, et al. Characterization of culturepositive adenovirus serotypes from respiratory specimens in Toronto, Ontario, Canada: September 2007-June 2008. Virol J 2009;6:11

6 Mitchell LS, Taylor B, Reimels W, Barrett FF, Devincenzo JP. Adenovirus 7a: a community-acquired outbreak in a children's hospital. Pediatr Infect Dis J 2000;19(10):996-1000

7 Kojaoghlanian T, Flomenberg P, Horwitz MS. The impact of adenovirus infection on the immunocompromised host. Rev Med Virol 2003;13(3):155-171

8 Chemaly RF, Ghosh S, Bodey GP, et al. Respiratory viral infections in adults with hematologic malignancies and human stem cell transplantation recipients: a retrospective study at a major cancer center. Medicine (Baltimore) 2006;85(5): 278-287

9 Kim Y-J, Boeckh M, Englund JA. Community respiratory virus infections in immunocompromised patients: hematopoietic stem cell and solid organ transplant recipients, and individuals with human immunodeficiency virus infection. Semin Respir Crit Care Med 2007;28(2):222-242

10 Moura PO, Roberto AF, Hein N, et al. Molecular epidemiology of human adenovirus isolated from children hospitalized with acute respiratory infection in São Paulo, Brazil. J Med Virol 2007;79(2): 174-181

11 Lin KH, Lin YC, Chen HL, et al. A two decade survey of respiratory adenovirus in Taiwan: the reemergence of adenovirus types 7 and 4. J Med Virol 2004;73(2):274-279

12 Li QG, Zheng QJ, Liu YH, Wadell G. Molecular epidemiology of adenovirus types 3 and 7 isolated from children with pneumonia in Beijing. J Med Virol 1996;49(3):170-177

13 Chen HL, Chiou SS, Hsiao HP, et al. Respiratory adenoviral infections in children: a study of hospitalized cases in southern Taiwan in 2001-2002. J Trop Pediatr 2004;50(5):279-284

14 Matthes-Martin S, Feuchtinger T, Shaw PJ, et al; Fourth European Conference on Infections in Leukemia. European guidelines for diagnosis and treatment of adenovirus infection in leukemia and stem cell transplantation: summary of ECIL-4 (2011). Transpl Infect Dis 2012;14(6):555-563

15 Breuer S, Rauch M, Matthes-Martin S, Lion T. Molecular diagnosis and management of viral infections in hematopoietic stem cell transplant recipients. Mol Diagn Ther 2012;16(2):63-77

16 Kolavic-Gray SA, Binn LN, Sanchez JL, et al. Large epidemic of adenovirus type 4 infection among military trainees: epidemiological, clinical, and laboratory studies. Clin Infect Dis 2002; 35(7):808-818

17 Sanchez JL, Binn LN, Innis BL, et al. Epidemic of adenovirusinduced respiratory illness among US military recruits: epidemiologic and immunologic risk factors in healthy, young adults. J Med Virol 2001;65(4):710-718 
18 Kajon AE, Moseley JM, Metzgar D, et al. Molecular epidemiology of adenovirus type 4 infections in US military recruits in the postvaccination era (1997-2003). J Infect Dis 2007;196(1):67-75

19 Ryan MA, Gray GC, Smith B, McKeehan JA, Hawksworth AW, Malasig MD. Large epidemic of respiratory illness due to adenovirus types 7 and 3 in healthy young adults. Clin Infect Dis 2002; 34(5):577-582

20 Russell KL, Hawksworth AW, Ryan MA, et al. Vaccine-preventable adenoviral respiratory illness in US military recruits, 1999-2004. Vaccine 2006;24(15):2835-2842

21 Centers for Disease Control and Prevention (CDC). Civilian outbreak of adenovirus acute respiratory disease-South Dakota, 1997. MMWR Morb Mortal Wkly Rep 1998;47(27):567-570

22 Zarraga AL, Kerns FT, Kitchen LW. Adenovirus pneumonia with severe sequelae in an immunocompetent adult. Clin Infect Dis 1992;15(4):712-713

23 Dudding BA, Wagner SC, Zeller JA, Gmelich JT, French GR, Top FH Jr. Fatal pneumonia associated with adenovirus type 7 in three military trainees. N Engl J Med 1972;286(24):1289-1292

24 Louie JK, Kajon AE, Holodniy M, et al. Severe pneumonia due to adenovirus serotype 14: a new respiratory threat? Clin Infect Dis 2008;46(3):421-425

25 Neofytos D, Ojha A, Mookerjee B, et al. Treatment of adenovirus disease in stem cell transplant recipients with cidofovir. Biol Blood Marrow Transplant 2007;13(1):74-81

26 Zheng X, Lu X, Erdman DD, et al. Identification of adenoviruses in specimens from high-risk pediatric stem cell transplant recipients and controls. J Clin Microbiol 2008;46(1):317-320

27 Symeonidis N, Jakubowski A, Pierre-Louis S, et al. Invasive adenoviral infections in T-cell-depleted allogeneic hematopoietic stem cell transplantation: high mortality in the era of cidofovir. Transpl Infect Dis 2007;9(2):108-113

28 Bordigoni P, Carret AS, Venard V, Witz F, Le Faou A. Treatment of adenovirus infections in patients undergoing allogeneic hematopoietic stem cell transplantation. Clin Infect Dis 2001;32(9): $1290-1297$

29 Lu X, Erdman DD. Molecular typing of human adenoviruses by PCR and sequencing of a partial region of the hexon gene. Arch Virol 2006;151(8):1587-1602

30 Henquell C, Boeuf B, Mirand A, et al. Fatal adenovirus infection in a neonate and transmission to health-care workers. J Clin Virol 2009;45(4):345-348

31 Lee J, Choi EH, Lee HJ. Comprehensive serotyping and epidemiology of human adenovirus isolated from the respiratory tract of Korean children over 17 consecutive years (1991-2007). J Med Virol 2010;82(4):624-631

32 Jones MS II, Harrach B, Ganac RD, et al. New adenovirus species found in a patient presenting with gastroenteritis. J Virol 2007; 81(11):5978-5984

33 Kajon AE, Lu X, Erdman DD, et al. Molecular epidemiology and brief history of emerging adenovirus 14 -associated respiratory disease in the United States. J Infect Dis 2010;202(1):93-103

34 Hage E, Huzly D, Ganzenmueller T, Beck R, Schulz TF, Heim A. A human adenovirus species $B$ subtype 21a associated with severe pneumonia. J Infect 2014;69(5):490-499

35 Robinson CM, Singh G, Lee JY, et al. Molecular evolution of human adenoviruses. Sci Rep 2013;3:1812

36 Hage E, Gerd Liebert U, Bergs S, Ganzenmueller T, Heim A. Human mastadenovirus type 70: a novel, multiple recombinant species $D$ mastadenovirus isolated from diarrhoeal faeces of a haematopoietic stem cell transplantation recipient. J Gen Virol 2015; 96(9):2734-2742

37 Kajon AE, Echavarria M, de Jong JC. Designation of human adenovirus types based on sequence data: an unfinished debate. J Clin Virol 2013;58(4):743-744

38 Echavarría M. Adenoviruses in immunocompromised hosts. Clin Microbiol Rev 2008;21(4):704-715
39 Kajon AE, Hang J, Hawksworth A, et al. Molecular Epidemiology of Adenovirus Type 21 Respiratory Strains Isolated From US Military Trainees (1996-2014). J Infect Dis 2015;212(6):871-880

40 Erdman DD, Xu W, Gerber SI, et al. Molecular epidemiology of adenovirus type 7 in the United States, 1966-2000. Emerg Infect Dis 2002;8(3):269-277

41 Houng HS, Gong H, Kajon AE, et al. Genome sequences of human adenovirus 14 isolates from mild respiratory cases and a fatal pneumonia, isolated during 2006-2007 epidemics in North America. Respir Res 2010;11:116

42 Ebner K, Rauch M, Preuner S, Lion T. Typing of human adenoviruses in specimens from immunosuppressed patients by PCRfragment length analysis and real-time quantitative PCR. J Clin Microbiol 2006;44(8):2808-2815

43 Walls T, Hawrami K, Ushiro-Lumb I, Shingadia D, Saha V, Shankar AG. Adenovirus infection after pediatric bone marrow transplantation: is treatment always necessary? Clin Infect Dis 2005;40(9): 1244-1249

44 Kajon AE, Dickson LM, Metzgar D, Houng HS, Lee V, Tan BH. Outbreak of febrile respiratory illness associated with adenovirus 11a infection in a Singapore military training cAMP. J Clin Microbiol 2010;48(4):1438-1441

45 Nakayama M, Miyazaki C, Ueda K, et al. Pharyngoconjunctival fever caused by adenovirus type 11. Pediatr Infect Dis J 1992; 11(1):6-9

46 Yin-Murphy M, Lim KH, Chua PH. Adenovirus type 11 epidemic conjunctivitis in Singapore. Southeast Asian J Trop Med Public Health 1974;5(3):333-341

47 Tai FH, Chu S, Chi WH, Wei HY, Hierholzer JC. Epidemic haemorrhagic conjunctivitis associated with adenovirus type 11 in Taiwan. Southeast Asian J Trop Med Public Health 1974;5(3):342-349

48 James L, Vernon MO, Jones RC, et al. Outbreak of human adenovirus type 3 infection in a pediatric long-term care facility-Illinois, 2005. Clin Infect Dis 2007;45(4):416-420

49 Ishiko H, Aoki K. Spread of epidemic keratoconjunctivitis due to a novel serotype of human adenovirus in Japan. J Clin Microbiol 2009;47(8):2678-2679

50 Filho EP, da Costa Faria NR, Fialho AM, et al. Adenoviruses associated with acute gastroenteritis in hospitalized and community children up to 5 years old in Rio de Janeiro and Salvador, Brazil. J Med Microbiol 2007;56(Pt 3):313-319

51 Madisch I, Wölfel R, Harste G, Pommer H, Heim A. Molecular identification of adenovirus sequences: a rapid scheme for early typing of human adenoviruses in diagnostic samples of immunocompetent and immunodeficient patients. J Med Virol 2006; 78(9):1210-1217

52 Hársi CM, Rolim DP, Gomes SA, et al. Adenovirus genome types isolated from stools of children with gastroenteritis in São Paulo, Brazil. J Med Virol 1995;45(2):127-134

53 Fukuda S, Kuwayama M, Takao S, Shimazu Y, Miyazaki K. Molecular epidemiology of subgenus $\mathrm{F}$ adenoviruses associated with pediatric gastroenteritis during eight years in Hiroshima Prefecture as a limited area. Arch Virol 2006;151(12):2511-2517

54 Sdiri-Loulizi K, Gharbi-Khelifi H, de Rougemont A, et al. Molecular epidemiology of human astrovirus and adenovirus serotypes $40 /$ 41 strains related to acute diarrhea in Tunisian children. J Med Virol 2009;81(11):1895-1902

55 Magwalivha M, Wolfaardt M, Kiulia NM, van Zyl WB, Mwenda JM, Taylor MB. High prevalence of species D human adenoviruses in fecal specimens from Urban Kenyan children with diarrhea. J Med Virol 2010;82(1):77-84

56 Gonçalves G, Gouveia E, Mesquita JR, et al. Outbreak of acute gastroenteritis caused by adenovirus type 41 in a kindergarten. Epidemiol Infect 2011;139(11):1672-1675

57 Li L, Shimizu H, Doan LT, et al. Characterizations of adenovirus type 41 isolates from children with acute gastroenteritis in Japan, Vietnam, and Korea. J Clin Microbiol 2004;42(9):4032-4039 
58 Marie-Cardine A, Gourlain K, Mouterde O, et al. Epidemiology of acute viral gastroenteritis in children hospitalized in Rouen, France. Clin Infect Dis 2002;34(9):1170-1178

59 Soares CC, Volotão EM, Albuquerque MC, et al. Prevalence of enteric adenoviruses among children with diarrhea in four Brazilian cities. J Clin Virol 2002;23(3):171-177

60 Cunliffe NA, Booth JA, Elliot C, et al. Healthcare-associated viral gastroenteritis among children in a large pediatric hospital, United Kingdom. Emerg Infect Dis 2010;16(1):55-62

61 Iturriza Gómara M, Simpson R, Perault AM, et al. Structured surveillance of infantile gastroenteritis in East Anglia, UK: incidence of infection with common viral gastroenteric pathogens. Epidemiol Infect 2008;136(1):23-33

62 King JC Jr. Community respiratory viruses in individuals with human immunodeficiency virus infection. Am J Med 1997;102 (3A):19-24, discussion 25-26

63 Wigger HJ, Blanc WA. Fatal hepatic and bronchial necrosis in adenovirus infection with thymic alymphoplasia. N Engl J Med 1966;275(16):870-874

64 Dagan R, Schwartz RH, Insel RA, Menegus MA. Severe diffuse adenovirus 7a pneumonia in a child with combined immunodeficiency: possible therapeutic effect of human immune serum globulin containing specific neutralizing antibody. Pediatr Infect Dis 1984;3(3):246-251

65 Barker JH, Luby JP, Sean Dalley A, Bartek WM, Burns DK, Erdman DD. Fatal type 3 adenoviral pneumonia in immunocompetent adult identical twins. Clin Infect Dis 2003;37(10):e142-e146

66 Buffington J, Chapman LE, Stobierski MG, et al. Epidemic keratoconjunctivitis in a chronic care facility: risk factors and measures for control. J Am Geriatr Soc 1993;41(11):1177-1181

67 Singh-Naz N, Brown M, Ganeshananthan M. Nosocomial adenovirus infection: molecular epidemiology of an outbreak. Pediatr Infect Dis J 1993;12(11):922-925

68 Lessa FC, Gould PL, Pascoe N, et al. Health care transmission of a newly emergent adenovirus serotype in health care personnel at a military hospital in Texas, 2007. J Infect Dis 2009;200(11): 1759-1765

69 Russell KL, Broderick MP, Franklin SE, et al. Transmission dynamics and prospective environmental sampling of adenovirus in a military recruit setting. J Infect Dis 2006;194(7):877-885

70 Garnett CT, Erdman D, Xu W, Gooding LR. Prevalence and quantitation of species $C$ adenovirus DNA in human mucosal lymphocytes. J Virol 2002;76(21):10608-10616

71 Bil-Lula I, Ussowicz M, Rybka B, et al. Hematuria due to adenoviral infection in bone marrow transplant recipients. Transplant Proc 2010;42(9):3729-3734

72 Wadell G. Molecular epidemiology of human adenoviruses. Curr Top Microbiol Immunol 1984;110:191-220

73 Mattner F, Sykora KW, Meissner B, Heim A. An adenovirus type F41 outbreak in a pediatric bone marrow transplant unit: analysis of clinical impact and preventive strategies. Pediatr Infect Dis J 2008;27(5):419-424

74 McNeill KM, Ridgely Benton F, Monteith SC, Tuchscherer MA, Gaydos JC. Epidemic spread of adenovirus type 4-associated acute respiratory disease between U.S. Army installations. Emerg Infect Dis 2000;6(4):415-419

75 Jeon $\mathrm{K}$, Kang CI, Yoon CH, et al. High isolation rate of adenovirus serotype 7 from South Korean military recruits with mild acute respiratory disease. Eur J Clin Microbiol Infect Dis 2007;26(7): 481-483

76 Padin DS, Faix D, Brodine S, et al. Retrospective analysis of demographic and clinical factors associated with etiology of febrile respiratory illness among US military basic trainees. BMC Infect Dis 2014;14:576

77 Sanchez MP, Erdman DD, Torok TJ, Freeman CJ, Matyas BT. Outbreak of adenovirus 35 pneumonia among adult residents and staff of a chronic care psychiatric facility. J Infect Dis 1997; 176(3):760-763
78 Finn A, Anday E, Talbot GH. An epidemic of adenovirus 7a infection in a neonatal nursery: course, morbidity, and management. Infect Control Hosp Epidemiol 1988;9(9):398-404

79 Klinger JR, Sanchez MP, Curtin LA, Durkin M, Matyas B. Multiple cases of life-threatening adenovirus pneumonia in a mental health care center. Am J Respir Crit Care Med 1998;157(2): 645-649

80 Gerber SI, Erdman DD, Pur SL, et al. Outbreak of adenovirus genome type $7 \mathrm{~d} 2$ infection in a pediatric chronic-care facility and tertiary-care hospital. Clin Infect Dis 2001;32(5):694-700

81 Zhu Z, Zhang Y, Xu S, et al. Outbreak of acute respiratory disease in China caused by B2 species of adenovirus type 11.J Clin Microbiol 2009;47(3):697-703

82 Harris DJ, Wulff H, Ray CG, Poland JD, Chin TD, Wenner HA. Viruses and disease. 3. An outbreak of adenovirus type 7A in a children's home. Am J Epidemiol 1971;93(5):399-402

83 Chany C, Lepine P, Lelong M, Le TV, Satge P, Virat J. Severe and fatal pneumonia in infants and young children associated with adenovirus infections. Am J Hyg 1958;67(3):367-378

84 Schmitz H, Wigand R, Heinrich W. Worldwide epidemiology of human adenovirus infections. Am J Epidemiol 1983;117(4): 455-466

85 Rubin BA. Clinical picture and epidemiology of adenovirus infections (a review). Acta Microbiol Hung 1993;40(4):303-323

86 Trei JS, Johns NM, Garner JL, et al. Spread of adenovirus to geographically dispersed military installations, May-October 2007. Emerg Infect Dis 2010;16(5):769-775

87 Sauerbrei A, Sehr K, Brandstädt A, Heim A, Reimer K, Wutzler P. Sensitivity of human adenoviruses to different groups of chemical biocides. J Hosp Infect 2004;57(1):59-66

88 Hong JY, Lee HJ, Piedra PA, et al. Lower respiratory tract infections due to adenovirus in hospitalized Korean children: epidemiology, clinical features, and prognosis. Clin Infect Dis 2001;32(10): 1423-1429

89 Lu QB, Tong YG, Wo Y, et al. Epidemiology of human adenovirus and molecular characterization of human adenovirus 55 in China, 2009-2012. Influenza Other Respi Viruses 2014;8(3):302-308

90 Hakim FA, Tleyjeh IM. Severe adenovirus pneumonia in immunocompetent adults: a case report and review of the literature. Eur J Clin Microbiol Infect Dis 2008;27(2):153-158

91 Cao B, Huang GH, Pu ZH, et al. Emergence of community-acquired adenovirus type 55 as a cause of community-onset pneumonia. Chest 2014;145(1):79-86

92 Sly PD, Soto-Quiros ME, Landau LI, Hudson I, Newton-John H. Factors predisposing to abnormal pulmonary function after adenovirus type 7 pneumonia. Arch Dis Child 1984;59(10):935-939

93 Cherry J. Adenoviruses. In: Feigin RD, Cherry JD, Demmler GJ, Kaplan SL, eds. Textbook of Pediatric Infectious Diseases, 5th ed. Vol. 2. Philadelphia: Saunders; 2003:1843-1856

94 Becroft DM. Bronchiolitis obliterans, bronchiectasis, and other sequelae of adenovirus type 21 infection in young children. J Clin Pathol 1971;24(1):72-82

95 Kalu SU, Loeffelholz M, Beck E, et al. Persistence of adenovirus nucleic acids in nasopharyngeal secretions: a diagnostic conundrum. Pediatr Infect Dis J 2010;29(8):746-750

96 Macek V, Sorli J, Kopriva S, Marin J. Persistent adenoviral infection and chronic airway obstruction in children. Am J Respir Crit Care Med 1994;150(1):7-10

97 Wurzel DF, Marchant JM, Yerkovich ST, et al. Prospective characterization of protracted bacterial bronchitis in children. Chest 2014;145(6):1271-1278

98 Wurzel DF, Mackay IM, Marchant JM, et al. Adenovirus species C is associated with chronic suppurative lung diseases in children. Clin Infect Dis 2014;59(1):34-40

99 Wurzel DF, Marchant JM, Clark JE, et al. Respiratory virus detection in nasopharyngeal aspirate versus bronchoalveolar lavage is dependent on virus type in children with chronic respiratory symptoms. J Clin Virol 2013;58(4):683-688 
100 Elliott WM, Hayashi S, Hogg JC. Immunodetection of adenoviral E1A proteins in human lung tissue. Am J Respir Cell Mol Biol 1995;12(6):642-648

101 Matsuse T, Hayashi S, Kuwano K, Keunecke H, Jefferies WA, Hogg JC. Latent adenoviral infection in the pathogenesis of chronic airways obstruction. Am Rev Respir Dis 1992;146(1):177-184

102 Percivalle E, Sarasini A, Torsellini M, et al. A comparison of methods for detecting adenovirus type 8 keratoconjunctivitis during a nosocomial outbreak in a Neonatal Intensive Care Unit. J Clin Virol 2003;28(3):257-264

103 Hamada N, Gotoh K, Hara K, et al. Nosocomial outbreak of epidemic keratoconjunctivitis accompanying environmental contamination with adenoviruses. J Hosp Infect 2008;68(3): 262-268

104 Ishiko H, Shimada Y, Konno T, et al. Novel human adenovirus causing nosocomial epidemic keratoconjunctivitis. J Clin Microbiol 2008;46(6):2002-2008

105 Tabbara KF, Omar N, Hammouda E, et al. Molecular epidemiology of adenoviral keratoconjunctivitis in Saudi Arabia. Mol Vis 2010; 16:2132-2136

106 Aoki K, Tagawa Y. A twenty-one year surveillance of adenoviral conjunctivitis in Sapporo, Japan. Int Ophthalmol Clin 2002;42(1): 49-54

107 Chang CH, Lin KH, Sheu MM, Huang WL, Wang HZ, Chen CW. The change of etiological agents and clinical signs of epidemic viral conjunctivitis over an 18-year period in southern Taiwan. Graefes Arch Clin Exp Ophthalmol 2003;241(7):554-560

108 Matsui K, Saha S, Saitoh M, et al. Isolation and identification of adenovirus from conjunctival scrapings over a two-year period (between 2001 and 2003) in Yokohama, Japan. J Med Virol 2007; 79(2):200-205

109 Jin XH, Ishiko H, Nguyen TH, et al. Molecular epidemiology of adenoviral conjunctivitis in Hanoi, Vietnam. Am J Ophthalmol 2006;142(6):1064-1066

110 Ariga T, Shimada Y, Shiratori K, et al. Five new genome types of adenovirus type 37 caused epidemic keratoconjunctivitis in Sapporo, Japan, for more than 10 years. J Clin Microbiol 2005; 43(2):726-732

111 Lee YC, Chen N, Huang IT, et al. Human adenovirus type 8 epidemic keratoconjunctivitis with large corneal epithelial fulllayer detachment: an endemic outbreak with uncommon manifestations. Clin Ophthalmol 2015;9:953-957

112 Centers for Disease Control and Prevention (CDC). Adenovirusassociated epidemic keratoconjunctivitis outbreaks-four states, 2008-2010. MMWR Morb Mortal Wkly Rep 2013;62(32): 637-641

113 Itakura S, Aoki K, Sawada H, Shinagawa M. Analysis with restriction endonucleases recognizing 4- or 5-base-pair sequences of human adenovirus type 3 isolated from ocular diseases in Sapporo, Japan. J Clin Microbiol 1990;28(10):2365-2369

114 Ariga T, Shimada Y, Ohgami K, et al. New genome type of adenovirus serotype 4 caused nosocomial infections associated with epidemic conjunctivitis in Japan. J Clin Microbiol 2004; 42(8):3644-3648

115 Montessori V, Scharf S, Holland S, Werker DH, Roberts FJ, Bryce E. Epidemic keratoconjunctivitis outbreak at a tertiary referral eye care clinic. Am J Infect Control 1998;26(4):399-405

116 Sendra-Gutiérrez JM, Martín-Rios D, Casas I, Sáez P, Tovar A, Moreno C. An outbreak of adenovirus type 8 keratoconjunctivitis in a nursing home in Madrid. Euro Surveill 2004;9(3):27-30

117 Saitoh-Inagawa W, Aoki K, Uchio E, Itoh N, Ohno S. Ten years' surveillance of viral conjunctivitis in Sapporo, Japan. Graefes Arch Clin Exp Ophthalmol 1999;237(1):35-38

118 Kuo IC, Espinosa C, Forman M, Pehar M, Maragakis LL, Valsamakis A. Detection and prevalence of adenoviral conjunctivitis among hospital employees using real-time polymerase chain reaction as an infection prevention tool. Infect Control Hosp Epidemiol 2014; 35(6):728-731
119 Kaneko H, Aoki K, Ishida S, et al. Recombination analysis of intermediate human adenovirus type 53 in Japan by complete genome sequence. J Gen Virol 2011;92(Pt 6):1251-1259

120 Huang G, Yao W, Yu W, et al. Outbreak of epidemic keratoconjunctivitis caused by human adenovirus type 56, China, 2012. PLoS ONE 2014;9(10):e110781

121 Enomoto M, Okafuji T, Okafuji T, et al. Isolation of an intertypic recombinant human adenovirus (candidate type 56) from the pharyngeal swab of a patient with pharyngoconjunctival fever. Jpn J Infect Dis 2012;65(5):457-459

122 Walsh MP, Chintakuntlawar A, Robinson CM, et al. Evidence of molecular evolution driven by recombination events influencing tropism in a novel human adenovirus that causes epidemic keratoconjunctivitis. PLoS ONE 2009;4(6):e5635

123 Kaneko H, Suzutani T, Aoki K, et al. Epidemiological and virological features of epidemic keratoconjunctivitis due to new human adenovirus type 54 in Japan. Br J Ophthalmol 2011;95(1):32-36

124 Hiroi S, Morikawa S, Takahashi K, Komano J, Kase T. Molecular epidemiology of human adenoviruses $d$ associated with epidemic keratoconjunctivitis in Osaka, Japan, 2001-2010. Jpn J Infect Dis 2013;66(5):436-438

125 Moyo SJ, Hanevik K, Blomberg B, et al. Prevalence and molecular characterisation of human adenovirus in diarrhoeic children in Tanzania; a case control study. BMC Infect Dis 2014;14:666

126 Kapelushnik J, Or R, Delukina M, Nagler A, Livni N, Engelhard D. Intravenous ribavirin therapy for adenovirus gastroenteritis after bone marrow transplantation. J Pediatr Gastroenterol Nutr 1995; 21(1):110-112

127 Janoff EN, Orenstein JM, Manischewitz JF, Smith PD. Adenovirus colitis in the acquired immunodeficiency syndrome. Gastroenterology 1991;100(4):976-979

128 Wang WH, Wang HL. Fulminant adenovirus hepatitis following bone marrow transplantation. A case report and brief review of the literature. Arch Pathol Lab Med 2003;127(5):e246-e248

129 Arav-Boger R, Echavarria M, Forman M, Charache P, Persaud D. Clearance of adenoviral hepatitis with ribavirin therapy in a pediatric liver transplant recipient. Pediatr Infect Dis J 2000; 19(11):1097-1100

130 Putra J, Suriawinata AA. Adenovirus hepatitis presenting as tumoral lesions in an immunocompromised patient. Ann Hepatol 2014;13(6):827-829

131 Yan Z, Nguyen S, Poles M, Melamed J, Scholes JV. Adenovirus colitis in human immunodeficiency virus infection: an underdiagnosed entity. Am J Surg Pathol 1998;22(9):1101-1106

132 Hedderwick SA, Greenson JK, McGaughy VR, Clark NM. Adenovirus cholecystitis in a patient with AIDS. Clin Infect Dis 1998; 26(4):997-999

133 Bateman CM, Kesson AM, Shaw PJ. Pancreatitis and adenoviral infection in children after blood and marrow transplantation. Bone Marrow Transplant 2006;38(12):807-811

134 Kir S, Aydin Y, Kocaman O, et al. Acute pancreatitis after severe opthalmic adenoviral infection. Acta Gastroenterol Belg 2011; 74(2):361-362

135 Yokose N, Hirakawa T, Inokuchi K. Adenovirus-associated hemorrhagic cystitis in a patient with plasma cell myeloma treated with bortezomib. Leuk Res 2009;33(8):e106

136 Akiyama H, Kurosu T, Sakashita C, et al. Adenovirus is a key pathogen in hemorrhagic cystitis associated with bone marrow transplantation. Clin Infect Dis 2001;32(9):1325-1330

137 Teramura T, Naya M, Yoshihara T, Kanoh G, Morimoto A, Imashuku S. Adenoviral infection in hematopoietic stem cell transplantation: early diagnosis with quantitative detection of the viral genome in serum and urine. Bone Marrow Transplant 2004; 33(1):87-92

138 Miyamura K, Hamaguchi M, Taji H, et al. Successful ribavirin therapy for severe adenovirus hemorrhagic cystitis after allogeneic marrow transplant from close HLA donors rather than distant donors. Bone Marrow Transplant 2000;25(5):545-548 
139 Fanourgiakis P, Georgala A, Vekemans M, et al. Intravesical instillation of cidofovir in the treatment of hemorrhagic cystitis caused by adenovirus type 11 in a bone marrow transplant recipient. Clin Infect Dis 2005;40(1):199-201

140 Hofland CA, Eron LJ, Washecka RM. Hemorrhagic adenovirus cystitis after renal transplantation. Transplant Proc 2004;36(10): 3025-3027

141 Ferreira GF, Oliveira RA, Lucon M, et al. Hemorrhagic cystitis secondary to adenovirus or herpes simplex virus infection following renal transplantation: four case reports. Transplant Proc 2009;41(10):4416-4419

142 Yagisawa T, Nakada T, Takahashi K, Toma H, Ota K, Yaguchi H. Acute hemorrhagic cystitis caused by adenovirus after kidney transplantation. Urol Int 1995;54(3):142-146

143 Keswani M, Moudgil A. Adenovirus-associated hemorrhagic cystitis in a pediatric renal transplant recipient. Pediatr Transplant 2007;11(5):568-571

144 Koga S, Shindo K, Matsuya F, Hori T, Kanda S, Kanetake H. Acute hemorrhagic cystitis caused by adenovirus following renal transplantation: review of the literature. J Urol 1993;149(4): 838-839

145 Lachiewicz AM, Cianciolo R, Miller MB, Derebail VK. Adenovirus causing fever, upper respiratory infection, and allograft nephritis complicated by persistent asymptomatic viremia. Transpl Infect Dis 2014;16(4):648-652

146 Sujeet K, Vasudev B, Desai P, et al. Acute kidney injury requiring dialysis secondary to adenovirus nephritis in renal transplant recipient. Transpl Infect Dis 2011;13(2):174-177

147 Bruno B, Zager RA, Boeckh MJ, et al. Adenovirus nephritis in hematopoietic stem-cell transplantation. Transplantation 2004; 77(7):1049-1057

148 Ito M, Hirabayashi N, Uno Y, Nakayama A, Asai J. Necrotizing tubulointerstitial nephritis associated with adenovirus infection. Hum Pathol 1991;22(12):1225-1231

149 Ardehali H, Volmar K, Roberts C, Forman M, Becker LC. Fatal disseminated adenoviral infection in a renal transplant patient. Transplantation 2001;71(7):998-999

150 Echavarria M, Forman M, van Tol MJ, Vossen JM, Charache P, Kroes AC. Prediction of severe disseminated adenovirus infection by serum PCR. Lancet 2001;358(9279):384-385

151 Mori K, Yoshihara T, Nishimura Y, et al. Acute renal failure due to adenovirus-associated obstructive uropathy and necrotizing tubulointerstitial nephritis in a bone marrow transplant recipient. Bone Marrow Transplant 2003;31(12):1173-1176

152 Liddle OL, Samuel MI, Sudhanva M, Ellis J, Taylor C. Adenovirus urethritis and concurrent conjunctivitis: a case series and review of the literature. Sex Transm Infect 2015;91(2):87-90

153 Sivaprakasam P, Carr TF, Coussons M, et al. Improved outcome from invasive adenovirus infection in pediatric patients after hemopoietic stem cell transplantation using intensive clinical surveillance and early intervention. J Pediatr Hematol Oncol 2007;29(2):81-85

154 Robin M, Marque-Juillet S, Scieux C, et al. Disseminated adenovirus infections after allogeneic hematopoietic stem cell transplantation: incidence, risk factors and outcome. Haematologica 2007; 92(9):1254-1257

155 Kroes AC, de Klerk EP, Lankester AC, et al. Sequential emergence of multiple adenovirus serotypes after pediatric stem cell transplantation. J Clin Virol 2007;38(4):341-347

156 de Mezerville MH, Tellier R, Richardson S, Hébert D, Doyle J, Allen U. Adenoviral infections in pediatric transplant recipients: a hospital-based study. Pediatr Infect Dis J 2006;25(9):815-818

157 Venard V, Carret A, Corsaro D, Bordigoni P, Le Faou A. Genotyping of adenoviruses isolated in an outbreak in a bone marrow transplant unit shows that diverse strains are involved. J Hosp Infect 2000;44(1):71-74

158 Hoffman JA, Shah AJ, Ross LA, Kapoor N. Adenoviral infections and a prospective trial of cidofovir in pediatric hematopoietic stem cell transplantation. Biol Blood Marrow Transplant 2001;7(7): 388-394

159 Kelsey DS. Adenovirus meningoencephalitis. Pediatrics 1978; 61(2):291-293

160 Ladisch S, Lovejoy FH, Hierholzer JC, et al. Extrapulmonary manifestations of adenovirus type 7 pneumonia simulating Reye syndrome and the possible role of an adenovirus toxin. J Pediatr 1979;95(3):348-355

161 Gray GC, McCarthy T, Lebeck MG, et al. Genotype prevalence and risk factors for severe clinical adenovirus infection, United States 2004-2006. Clin Infect Dis 2007;45(9):1120-1131

162 Huang YC, Huang SL, Chen SP, et al. Adenovirus infection associated with central nervous system dysfunction in children. J Clin Virol 2013;57(4):300-304

163 Dubberke ER, Tu B, Rivet DJ, et al. Acute meningoencephalitis caused by adenovirus serotype 26. J Neurovirol 2006;12(3): 235-240

164 Reyes-Andrade J, Sánchez-Céspedes J, Olbrich P, et al. Meningoencephalitis due to adenovirus in a healthy infant mimicking severe bacterial sepsis. Pediatr Infect Dis J 2014;33(4):416-419

165 Frange P, Peffault de Latour R, Arnaud C, et al. Adenoviral infection presenting as an isolated central nervous system disease without detectable viremia in two children after stem cell transplantation. J Clin Microbiol 2011;49(6):2361-2364

166 Bowles NE, Ni J, Kearney DL, et al. Detection of viruses in myocardial tissues by polymerase chain reaction. evidence of adenovirus as a common cause of myocarditis in children and adults. J Am Coll Cardiol 2003;42(3):466-472

167 Valdés O, Acosta B, Piñón A, et al. First report on fatal myocarditis associated with adenovirus infection in Cuba. J Med Virol 2008; 80(10):1756-1761

168 Melón S, Méndez S, Iglesias B, et al. Involvement of adenovirus in clinical mononucleosis-like syndromes in young children. Eur J Clin Microbiol Infect Dis 2005;24(5):314-318

169 Couroucli XI, Welty SE, Ramsay PL, et al. Detection of microorganisms in the tracheal aspirates of preterm infants by polymerase chain reaction: association of adenovirus infection with bronchopulmonary dysplasia. Pediatr Res 2000;47(2):225-232

170 Guarner J, de Leon-Bojorge B, Lopez-Corella E, et al. Intestinal intussusception associated with adenovirus infection in Mexican children. Am J Clin Pathol 2003;120(6):845-850

171 Bajanowski T, Wiegand P, Cecchi R, et al. Detection and significance of adenoviruses in cases of sudden infant death. Virchows Arch 1996;428(2):113-118

172 Rodríguez-Martínez CE, Rodríguez DA, Nino G. Respiratory syncytial virus, adenoviruses, and mixed acute lower respiratory infections in children in a developing country. J Med Virol 2015; 87(5):774-781

173 Russell KL, Baker CI, Hansen C, et al. Lack of effectiveness of the 23-valent polysaccharide pneumococcal vaccine in reducing allcause pneumonias among healthy young military recruits: a randomized, double-blind, placebo-controlled trial. Vaccine 2015;33(9):1182-1187

174 Top FH Jr. Control of adenovirus acute respiratory disease in U.S. Army trainees. Yale J Biol Med 1975;48(3):185-195

175 Radin JM, Hawksworth AW, Blair PJ, et al. Dramatic decline of respiratory illness among US military recruits after the renewed use of adenovirus vaccines. Clin Infect Dis 2014;59(7):962-968

176 Barraza EM, Ludwig SL, Gaydos JC, Brundage JF. Reemergence of adenovirus type 4 acute respiratory disease in military trainees: report of an outbreak during a lapse in vaccination. J Infect Dis 1999;179(6):1531-1533

177 Hendrix RM, Lindner JL, Benton FR, et al. Large, persistent epidemic of adenovirus type 4-associated acute respiratory disease in U.S. army trainees. Emerg Infect Dis 1999;5(6): 798-801

178 Gray GC, Goswami PR, Malasig MD, et al; For the Adenovirus Surveillance Group. Adult adenovirus infections: loss of 
orphaned vaccines precipitates military respiratory disease epidemics. Clin Infect Dis 2000;31(3):663-670

179 Kuschner RA, Russell KL, Abuja M, et al; Adenovirus Vaccine Efficacy Trial Consortium. A phase 3, randomized, double-blind, placebo-controlled study of the safety and efficacy of the live, oral adenovirus type 4 and type 7 vaccine, in U.S. military recruits. Vaccine 2013;31(28):2963-2971

180 Leen AM, Rooney CM. Adenovirus as an emerging pathogen in immunocompromised patients. Br J Haematol 2005;128(2): 135-144

181 Baldwin A, Kingman H, Darville M, et al. Outcome and clinical course of 100 patients with adenovirus infection following bone marrow transplantation. Bone Marrow Transplant 2000;26(12):1333-1338

182 La Rosa AM, Champlin RE, Mirza N, et al. Adenovirus infections in adult recipients of blood and marrow transplants. Clin Infect Dis 2001;32(6):871-876

183 George D, El-Mallawany NK, Jin Z, et al. Adenovirus infection in paediatric allogeneic stem cell transplantation recipients is a major independent factor for significantly increasing the risk of treatment related mortality. Br J Haematol 2012;156(1):99-108

184 Fowler CJ, Dunlap J, Troyer D, Stenzel P, Epner E, Maziarz RT. Lifethreatening adenovirus infections in the setting of the immunocompromised allogeneic stem cell transplant patients. Adv Hematol 2010;2010:601548

185 Abinun M, Flood TJ, Cant AJ, et al. Autologous T cell depleted haematopoietic stem cell transplantation in children with severe juvenile idiopathic arthritis in the UK (2000-2007). Mol Immunol 2009;47(1):46-51

186 Kohno K, Nagafuji K, Tsukamoto H, et al. Infectious complications in patients receiving autologous CD34-selected hematopoietic stem cell transplantation for severe autoimmune diseases. Transpl Infect Dis 2009;11(4):318-323

187 Mori Y, Miyamoto T, Kamezaki K, et al. Low incidence of adenovirus hemorrhagic cystitis following autologous hematopoietic stem cell transplantation in the rituximab era. Am J Hematol 2012;87(8):828-830

188 Yusuf U, Hale GA, Carr J, et al. Cidofovir for the treatment of adenoviral infection in pediatric hematopoietic stem cell transplant patients. Transplantation 2006;81(10):1398-1404

189 Leruez-Ville M, Minard V, Lacaille F, et al. Real-time blood plasma polymerase chain reaction for management of disseminated adenovirus infection. Clin Infect Dis 2004;38(1):45-52

190 Runde V, Ross S, Trenschel R, et al. Adenoviral infection after allogeneic stem cell transplantation (SCT): report on 130 patients from a single SCT unit involved in a prospective multi center surveillance study. Bone Marrow Transplant 2001;28(1):51-57

191 Lee YJ, Chung D, Xiao K, et al. Adenovirus viremia and disease: comparison of $\mathrm{T}$ cell-depleted and conventional hematopoietic stem cell transplantation recipients from a single institution. Biol Blood Marrow Transplant 2013;19(3):387-392

192 Muller WJ, Levin MJ, Shin YK, et al. Clinical and in vitro evaluation of cidofovir for treatment of adenovirus infection in pediatric hematopoietic stem cell transplant recipients. Clin Infect Dis 2005;41(12):1812-1816

193 Sive JI, Thomson KJ, Morris EC, Ward KN, Peggs KS. Adenoviremia has limited clinical impact in the majority of patients following alemtuzumab-based allogeneic stem cell transplantation in adults. Clin Infect Dis 2012;55(10):1362-1370

194 Lankester AC, van Tol MJ, Claas EC, Vossen JM, Kroes AC. Quantification of adenovirus DNA in plasma for management of infection in stem cell graft recipients. Clin Infect Dis 2002;34(6):864-867

195 Schilham MW, Claas EC, van Zaane W, et al. High levels of adenovirus DNA in serum correlate with fatal outcome of adenovirus infection in children after allogeneic stem-cell transplantation. Clin Infect Dis 2002;35(5):526-532

196 Humar A, Kumar D, Mazzulli T, et al; PV16000 Study Group. A surveillance study of adenovirus infection in adult solid organ transplant recipients. Am J Transplant 2005;5(10):2555-2559
197 Hierholzer JC. Adenoviruses in the immunocompromised host. Clin Microbiol Rev 1992;5(3):262-274

198 Michaels MG, Green M, Wald ER, Starzl TE. Adenovirus infection in pediatric liver transplant recipients. J Infect Dis 1992;165(1): 170-174

199 McGrath D, Falagas ME, Freeman R, et al. Adenovirus infection in adult orthotopic liver transplant recipients: incidence and clinical significance. J Infect Dis 1998;177(2):459-462

200 Bridges ND, Spray TL, Collins MH, Bowles NE, Towbin JA. Adenovirus infection in the lung results in graft failure after lung transplantation. J Thorac Cardiovasc Surg 1998;116(4): 617-623

201 Florescu MC, Miles CD, Florescu DF. What do we know about adenovirus in renal transplantation? Nephrol Dial Transplant 2013;28(8):2003-2010

202 Watcharananan SP, Avery R, Ingsathit A, et al. Adenovirus disease after kidney transplantation: course of infection and outcome in relation to blood viral load and immune recovery. Am J Transplant 2011;11(6):1308-1314

203 Florescu DF, Kwon JY, Dumitru I. Adenovirus infections in heart transplantation. Cardiol Rev 2013;21(4):203-206

204 Bruminhent J, Athas DM, Hess BD, Flomenberg P. Disseminated adenovirus disease in heart transplant recipient presenting with conjunctivitis. Transpl Infect Dis 2015;17(1):125-128

205 McLaughlin GE, Delis S, Kashimawo L, et al. Adenovirus infection in pediatric liver and intestinal transplant recipients: utility of DNA detection by PCR. Am J Transplant 2003;3(2):224-228

206 Florescu DF, Islam MK, Mercer DF, et al. Adenovirus infections in pediatric small bowel transplant recipients. Transplantation 2010;90(2):198-204

207 Ohori NP, Michaels MG, Jaffe R, Williams P, Yousem SA. Adenovirus pneumonia in lung transplant recipients. Hum Pathol 1995; 26(10):1073-1079

208 Humar A, Doucette K, Kumar D, et al. Assessment of adenovirus infection in adult lung transplant recipients using molecular surveillance. J Heart Lung Transplant 2006;25(12):1441-1446

209 Doan ML, Mallory GB, Kaplan SL, et al. Treatment of adenovirus pneumonia with cidofovir in pediatric lung transplant recipients. J Heart Lung Transplant 2007;26(9):883-889

210 Florescu DF, Hoffman JA; AST Infectious Diseases Community of Practice. Adenovirus in solid organ transplantation. Am J Transplant 2013;13(4, Suppl 4):206-211

211 Moulik M, Breinholt JP, Dreyer WJ, et al. Viral endomyocardial infection is an independent predictor and potentially treatable risk factor for graft loss and coronary vasculopathy in pediatric cardiac transplant recipients. J Am Coll Cardiol 2010;56(7): 582-592

212 Shirali GS, Ni J, Chinnock RE, et al. Association of viral genome with graft loss in children after cardiac transplantation. N Engl J Med 2001;344(20):1498-1503

213 Schowengerdt KO, Ni J, Denfield SW, et al. Diagnosis, surveillance, and epidemiologic evaluation of viral infections in pediatric cardiac transplant recipients with the use of the polymerase chain reaction. J Heart Lung Transplant 1996;15(2):111-123

214 Simsir A, Greenebaum E, Nuovo G, Schulman LL. Late fatal adenovirus pneumonitis in a lung transplant recipient. Transplantation 1998;65(4):592-594

215 Ferdman RM, Ross L, Inderlied C, Church JA. Adenovirus viremia in human immunodeficiency virus-infected children. Pediatr Infect Dis J 1997;16(4):413-415

216 Khoo SH, Bailey AS, de Jong JC, Mandal BK. Adenovirus infections in human immunodeficiency virus-positive patients: clinical features and molecular epidemiology. J Infect Dis 1995;172(3): 629-637

217 Kolawole OM, Oladosu TO, Abdulkarim AA, Okoh AI. Prevalence of adenovirus respiratory tract and hiv co-infections in patients attending the University of Ilorin, teaching hospital, Ilorin, Nigeria. BMC Res Notes 2014;7:870 
218 de Jong PJ, Valderrama G, Spigland I, Horwitz MS. Adenovirus isolates from urine of patients with acquired immunodeficiency syndrome. Lancet 1983;1(8337):1293-1296

219 Winkelstein JA, Marino MC, Lederman HM, et al. X-linked agammaglobulinemia: report on a United States registry of 201 patients. Medicine (Baltimore) 2006;85(4):193-202

220 Baum S. Adenovirus. In: Mandell GL, Bennett JE, Dolin R, eds. Mandell, Douglas, and Bennett's Principles and Practice of Infectious Diseases. 6th ed. Philadelphia, PA: Elsevier Churchill Livingstone; 2005:1835-1841

221 Centers for Disease Control and Prevention (CDC). Acute respiratory disease associated with adenovirus serotype 14-four states, 2006-2007. MMWR Morb Mortal Wkly Rep 2007;56(45): $1181-1184$

222 Esposito DH, Gardner TJ, Schneider E, et al. Outbreak of pneumonia associated with emergent human adenovirus serotype 14Southeast Alaska, 2008. J Infect Dis 2010;202(2):214-222

223 Chmielewicz B, Benzler J, Pauli G, Krause G, Bergmann F, Schweiger B. Respiratory disease caused by a species B2 adenovirus in a military camp in Turkey. J Med Virol 2005;77(2): 232-237

224 Kajon AE, Mistchenko AS, Videla C, Hortal M, Wadell G, Avendaño LF. Molecular epidemiology of adenovirus acute lower respiratory infections of children in the south cone of South America (1991-1994). J Med Virol 1996;48(2):151-156

225 Ison MG, Green M; AST Infectious Diseases Community of Practice. Adenovirus in solid organ transplant recipients. Am J Transplant 2009;9(4, Suppl 4):S161-S165

226 Elnifro EM, Cooper RJ, Klapper PE, Bailey AS, Tullo AB. Diagnosis of viral and chlamydial keratoconjunctivitis: which laboratory test? Br J Ophthalmol 1999;83(5):622-627

227 Uhnoo I, Wadell G, Svensson L, Johansson ME. Importance of enteric adenoviruses 40 and 41 in acute gastroenteritis in infants and young children. J Clin Microbiol 1984;20(3):365-372

228 Wold W, Horwitz M. Adenoviruses. In: Knipe DM, Howley PM, eds. Fields Virology. 5th ed. Philadelphia, PA: Lippincott, Williams \& Wilkins, Inc.; 2007:2395-2436

229 Suparno C, Milligan DW, Moss PA, Mautner V. Adenovirus infections in stem cell transplant recipients: recent developments in understanding of pathogenesis, diagnosis and management. Leuk Lymphoma 2004;45(5):873-885

230 van Kraaij MG, van Elden LJ, van Loon AM, et al. Frequent detection of respiratory viruses in adult recipients of stem cell transplants with the use of real-time polymerase chain reaction, compared with viral culture. Clin Infect Dis 2005;40(5):662-669

231 Wallot MA, Dohna-Schwake C, Auth M, et al. Disseminated adenovirus infection with respiratory failure in pediatric liver transplant recipients: impact of intravenous cidofovir and inhaled nitric oxide. Pediatr Transplant 2006;10(1):121-127

232 Landry ML, Lebeck MG, Capuano AW, McCarthy T, Gray GC. Adenovirus type 3 outbreak in connecticut associated with a novel variant. J Med Virol 2009;81(8):1380-1384

233 Adhikary AK, Inada T, Banik U, Numaga J, Okabe N. Identification of subgenus $C$ adenoviruses by fiber-based multiplex PCR. J Clin Microbiol 2004;42(2):670-673

234 Kajon AE, Erdman DD. Assessment of genetic variability among subspecies b1 human adenoviruses for molecular epidemiology studies. Methods Mol Med 2007;131:335-355

$235 \mathrm{Xu} \mathrm{W}$, Erdman DD. Type-specific identification of human adenovirus 3, 7, and 21 by a multiplex PCR assay. J Med Virol 2001; 64(4):537-542

236 Li QG, Wadell G. Analysis of 15 different genome types of adenovirus type 7 isolated on five continents. J Virol 1986; 60(1):331-335

237 Robinson CM, Zhou X, Rajaiya J, et al. Predicting the next eye pathogen: analysis of a novel adenovirus. MBio 2013;4(2): e00595-e12
238 Robinson CM, Seto D, Jones MS, Dyer DW, Chodosh J. Molecular evolution of human species D adenoviruses. Infect Genet Evol 2011;11(6):1208-1217

239 Robinson CM, Singh G, Henquell C, et al. Computational analysis and identification of an emergent human adenovirus pathogen implicated in a respiratory fatality. Virology 2011;409(2): 141-147

240 Zhang Q, Seto D, Cao B, Zhao S, Wan C. Genome sequence of human adenovirus type 55, a re-emergent acute respiratory disease pathogen in China. J Virol 2012;86(22):12441-12442

241 Seto D, Chodosh J, Brister JR, Jones MS; Members of the Adenovirus Research Community. Using the whole-genome sequence to characterize and name human adenoviruses. J Virol 2011;85(11): 5701-5702

242 Yamadera S, Yamashita K, Akatsuka M, Kato N, Inouye S. Trend of adenovirus type 7 infection, an emerging disease in Japan. A report of the National Epidemiological Surveillance of Infectious Agents in Japan. Jpn J Med Sci Biol 1998;51(1):43-51

243 Azar R, Varsano N, Mileguir F, Mendelson E. Molecular epidemiology of adenovirus type 7 in Israel: identification of two new genome types, Ad7k and Ad7d2.J Med Virol 1998;54(4):291-299

244 Wadell G, Cooney MK, da Costa Linhares A, et al. Molecular epidemiology of adenoviruses: global distribution of adenovirus 7 genome types. J Clin Microbiol 1985;21(3):403-408

245 Metzgar D, Osuna M, Yingst S, et al. PCR analysis of egyptian respiratory adenovirus isolates, including identification of species, serotypes, and coinfections. J Clin Microbiol 2005;43(11): 5743-5752

246 Kajon AE, Wadell G. Molecular epidemiology of adenoviruses associated with acute lower respiratory disease of children in Buenos Aires, Argentina (1984-1988). J Med Virol 1992;36(4): 292-297

247 Piedra PA, Poveda GA, Ramsey B, McCoy K, Hiatt PW. Incidence and prevalence of neutralizing antibodies to the common adenoviruses in children with cystic fibrosis: implication for gene therapy with adenovirus vectors. Pediatrics 1998;101(6): 1013-1019

248 Cooper RJ, Hallett R, Tullo AB, Klapper PE. The epidemiology of adenovirus infections in Greater Manchester, UK 1982-96. Epidemiol Infect 2000;125(2):333-345

249 Kim YJ, Hong JY, Lee HJ, et al. Genome type analysis of adenovirus types 3 and 7 isolated during successive outbreaks of lower respiratory tract infections in children. J Clin Microbiol 2003; 41(10):4594-4599

250 Murtagh P, Cerqueiro C, Halac A, Avila M, Kajon A. Adenovirus type $7 \mathrm{~h}$ respiratory infections: a report of 29 cases of acute lower respiratory disease. Acta Paediatr 1993;82(6-7):557-561

251 Li QG, Wadell G. Comparison of 17 genome types of adenovirus type 3 identified among strains recovered from six continents. J Clin Microbiol 1988;26(5):1009-1015

252 Adrian T, Best B, Hierholzer JC, Wigand R. Molecular epidemiology and restriction site mapping of adenovirus type 3 genome types. J Clin Microbiol 1989;27(6):1329-1334

253 Cassir N, Hraiech S, Nougairede A, Zandotti C, Fournier PE, Papazian L. Outbreak of adenovirus type 1 severe pneumonia in a French intensive care unit, September-October 2012. Euro Surveill 2014;19(39):20914

254 Rebelo-de-Andrade H, Pereira C, Gíria M, et al. Outbreak of acute respiratory infection among infants in Lisbon, Portugal, caused by human adenovirus serotype 3 and a new $7 / 3$ recombinant strain. J Clin Microbiol 2010;48(4):1391-1396

255 Kandel R, Srinivasan A, D’Agata EM, Lu X, Erdman D, Jhung M. Outbreak of adenovirus type 4 infection in a long-term care facility for the elderly. Infect Control Hosp Epidemiol 2010;31(7): 755-757

256 Top FH Jr, Buescher EL, Bancroft WH, Russell PK. Immunization with live types 7 and 4 adenovirus vaccines. II. Antibody response 
and protective effect against acute respiratory disease due to adenovirus type 7. J Infect Dis 1971;124(2):155-160

257 Top FH Jr, Grossman RA, Bartelloni PJ, et al. Immunization with live types 7 and 4 adenovirus vaccines. I. Safety, infectivity, antigenicity, and potency of adenovirus type 7 vaccine in humans. J Infect Dis 1971;124(2):148-154

258 Choi EH, Kim HS, Eun BW, et al. Adenovirus type 7 peptide diversity during outbreak, Korea, 1995-2000. Emerg Infect Dis 2005;11(5):649-654

259 Noda M, Yoshida T, Sakaguchi T, Ikeda Y, Yamaoka K, Ogino T. Molecular and epidemiological analyses of human adenovirus type 7 strains isolated from the 1995 nationwide outbreak in Japan. J Clin Microbiol 2002;40(1):140-145

260 Cho CT, Hiatt WO, Behbehani AM. Pneumonia and massive pleural effusion associated with adenovirus type 7. Am J Dis Child 1973;126(1):92-94

261 Yamamoto D, Okamoto M, Lupisan S, et al. Impact of human adenovirus serotype 7 in hospitalized children with severe fatal pneumonia in the Philippines. Jpn J Infect Dis 2014;67(2): $105-110$

262 Zhao S, Wan C, Ke C, et al. Re-emergent human adenovirus genome type $7 \mathrm{~d}$ caused an acute respiratory disease outbreak in Southern China after a twenty-one year absence. Sci Rep 2014; 4:7365

263 Brown RS, Nogrady MB, Spence L, Wiglesworth FW. An outbreak of adenovirus type 7 infection in children in Montreal. Can Med Assoc J 1973;108(4):434-439

264 Wadell G, Varsányi TM, Lord A, Sutton RN. Epidemic outbreaks of adenovirus 7 with special reference to the pathogenicity of adenovirus genome type 7b. Am J Epidemiol 1980;112(5): 619-628

265 Cui X, Wen L, Wu Z, et al. Human adenovirus type 7 infection associated with severe and fatal acute lower respiratory illness and nosocomial transmission. J Clin Microbiol 2015;53(2): 746-749

266 Centers for Disease Control (CDC). Adenovirus type 7 outbreak in a pediatric chronic-care facility-Pennsylvania, 1982. MMWR Morb Mortal Wkly Rep 1983;32(19):258-260

267 Kajon A, Wadell G. Genome analysis of South American adenovirus strains of serotype 7 collected over a 7-year period. J Clin Microbiol 1994;32(9):2321-2323

268 de Silva LM, Colditz P, Wadell G. Adenovirus type 7 infections in children in New South Wales, Australia. J Med Virol 1989;29(1): 28-32

269 Straube RC, Thompson MA, Van Dyke RB, et al. Adenovirus type 7b in a children's hospital. J Infect Dis 1983;147(5):814-819

270 Sakata H, Taketazu G, Nagaya K, et al. Outbreak of severe infection due to adenovirus type 7 in a paediatric ward in Japan. J Hosp Infect 1998;39(3):207-211

271 Tang L, Wang L, Tan X, Xu W. Adenovirus serotype 7 associated with a severe lower respiratory tract disease outbreak in infants in Shaanxi Province, China. Virol J 2011;8:23

272 Ersoy Y, Otlu B, Türkçüoğlu P, Yetkin F, Aker S, Kuzucu C. Outbreak of adenovirus serotype 8 conjunctivitis in preterm infants in a neonatal intensive care unit. J Hosp Infect 2012;80(2):144-149

273 Adhikary AK, Banik U. Human adenovirus type 8: the major agent of epidemic keratoconjunctivitis (EKC). J Clin Virol 2014;61(4): 477-486

274 Metzgar D, Osuna M, Kajon AE, Hawksworth AW, Irvine M, Russell KL. Abrupt emergence of diverse species B adenoviruses at US military recruit training centers. J Infect Dis 2007;196(10): 1465-1473

275 Asim M, Chong-Lopez A, Nickeleit V. Adenovirus infection of a renal allograft. Am J Kidney Dis 2003;41(3):696-701

276 Kendall EJ, Riddle RW, Tuck HA, Rodan KS, Andrews BE, McDonald JC. Pharyngo-conjunctival fever; school outbreaks in England during the summer of 1955 associated with adenovirus types 3, 7, and 14. BMJ 1957;2(5037):131-136
277 Tate JE, Bunning ML, Lott L, et al. Outbreak of severe respiratory disease associated with emergent human adenovirus serotype 14 at a US air force training facility in 2007. J Infect Dis 2009;199(10): 1419-1426

278 Lewis PF, Schmidt MA, Lu X, et al. A community-based outbreak of severe respiratory illness caused by human adenovirus serotype 14. J Infect Dis 2009;199(10):1427-1434

279 O'Flanagan D, O'Donnell J, Domegan L, et al. First reported cases of human adenovirus serotype 14p1 infection, Ireland, October 2009 to July 2010. Euro Surveill 2011;16(8):1-5

280 Van Der Veen J, Dijkman JH. Association of type 21 adenovirus with acute respiratory illness in military recruits. Am J Hyg 1962; 76:149-159

281 van der Avoort HG, Adrian T, Wigand R, Wermenbol AG, Zomerdijk TP, de Jong JC. Molecular epidemiology of adenovirus type 21 in the Netherlands and the Federal Republic of Germany from 1960 to 1985. J Clin Microbiol 1986;24(6):1084-1088

282 Larsen RA, Jacobson JT, Jacobson JA, Strikas RA, Hierholzer JC. Hospital-associated epidemic of pharyngitis and conjunctivitis caused by adenovirus $(21 / \mathrm{H} 21+35)$. J Infect Dis 1986;154(4): 706-709

283 Shult PA, Polyak F, Dick EC, Warshauer DM, King LA, Mandel AD. Adenovirus 21 infection in an isolated antarctic station: transmission of the virus and susceptibility of the population. Am J Epidemiol 1991;133(6):599-607

284 Ooi MH, Wong SC, Clear D, et al. Adenovirus type 21-associated acute flaccid paralysis during an outbreak of hand-foot-andmouth disease in Sarawak, Malaysia. Clin Infect Dis 2003; 36(5):550-559

285 Cardosa MJ, Krishnan S, Tio PH, Perera D, Wong SC. Isolation of subgenus B adenovirus during a fatal outbreak of enterovirus 71associated hand, foot, and mouth disease in Sibu, Sarawak. Lancet 1999;354(9183):987-991

286 Seidemann K, Heim A, Pfister ED, et al. Monitoring of adenovirus infection in pediatric transplant recipients by quantitative PCR: report of six cases and review of the literature. Am J Transplant 2004;4(12):2102-2108

287 Kampmann B, Cubitt D, Walls T, et al. Improved outcome for children with disseminated adenoviral infection following allogeneic stem cell transplantation. Br J Haematol 2005;130(4): 595-603

288 Leruez-Ville M, Chardin-Ouachée M, Neven B, et al. Description of an adenovirus A31 outbreak in a paediatric haematology unit. Bone Marrow Transplant 2006;38(1):23-28

289 Slatter MA, Read S, Taylor CE, et al. Adenovirus type F subtype 41 causing disseminated disease following bone marrow transplantation for immunodeficiency. J Clin Microbiol 2005;43(3): $1462-1464$

290 Li X, Kong M, Su X, et al. An outbreak of acute respiratory disease in China caused by human adenovirus type B55 in a physical training facility. Int J Infect Dis 2014;28:117-122

291 Sun B, He H, Wang Z, et al. Emergent severe acute respiratory distress syndrome caused by adenovirus type 55 in immunocompetent adults in 2013: a prospective observational study. Crit Care 2014;18(4):456

292 Kajon AE, de Jong JC, Dickson LM, et al. Molecular and serological characterization of species B2 adenovirus strains isolated from children hospitalized with acute respiratory disease in Buenos Aires, Argentina. J Clin Virol 2013;58(1):4-10

293 Hierholzer JC, Pumarola A. Antigenic characterization of intermediate adenovirus 14-11 strains associated with upper respiratory illness in a military camp. Infect Immun 1976;13(2): 354-359

294 Li QG, Hambraeus J, Wadell G. Genetic relationship between thirteen genome types of adenovirus 11,34 , and 35 with different tropisms. Intervirology 1991;32(6):338-350

295 Erard V, Huang ML, Ferrenberg J, et al. Quantitative real-time polymerase chain reaction for detection of adenovirus after $\mathrm{T}$ 
cell-replete hematopoietic cell transplantation: viral load as a marker for invasive disease. Clin Infect Dis 2007;45(8):958-965

296 Lankester AC, Heemskerk B, Claas EC, et al. Effect of ribavirin on the plasma viral DNA load in patients with disseminating adenovirus infection. Clin Infect Dis 2004;38(11):1521-1525

297 Lion T, Kosulin K, Landlinger C, et al. Monitoring of adenovirus load in stool by real-time PCR permits early detection of impending invasive infection in patients after allogeneic stem cell transplantation. Leukemia 2010;24(4):706-714

298 Sarantis H, Johnson G, Brown M, Petric M, Tellier R. Comprehensive detection and serotyping of human adenoviruses by PCR and sequencing. J Clin Microbiol 2004;42(9):3963-3969

299 Kajon AE, Dickson LM, Murtagh P, Viale D, Carballal G, Echavarria M. Molecular characterization of an adenovirus 3-16 intertypic recombinant isolated in Argentina from an infant hospitalized with acute respiratory infection. J Clin Microbiol 2010;48(4):1494-1496

300 Kajon AE, Lamson D, Shudt M, et al. Identification of a novel intertypic recombinant species $D$ human adenovirus in a pediatric stem cell transplant recipient. J Clin Virol 2014;61(4):496-502

301 Naesens L, Lenaerts L, Andrei G, et al. Antiadenovirus activities of several classes of nucleoside and nucleotide analogues. Antimicrob Agents Chemother 2005;49(3):1010-1016

302 Morfin F, Dupuis-Girod S, Mundweiler S, et al. In vitro susceptibility of adenovirus to antiviral drugs is species-dependent. Antivir Ther 2005;10(2):225-229

303 Gavin PJ, Katz BZ. Intravenous ribavirin treatment for severe adenovirus disease in immunocompromised children. Pediatrics 2002;110(1 Pt 1):e9

304 Bhadri VA, Lee-Horn L, Shaw PJ. Safety and tolerability of cidofovir in high-risk pediatric patients. Transpl Infect Dis 2009;11(4): 373-379

305 Hartline CB, Gustin KM, Wan WB, et al. Ether lipid-ester prodrugs of acyclic nucleoside phosphonates: activity against adenovirus replication in vitro. J Infect Dis 2005;191(3):396-399

306 Toth K, Spencer JF, Dhar D, et al. Hexadecyloxypropyl-cidofovir, CMX001, prevents adenovirus-induced mortality in a permissive, immunosuppressed animal model. Proc Natl Acad Sci U S A 2008; 105(20):7293-7297

307 Tollefson AE, Spencer JF, Ying B, Buller RM, Wold WS, Toth K. Cidofovir and brincidofovir reduce the pathology caused by systemic infection with human type 5 adenovirus in immunosuppressed Syrian hamsters, while ribavirin is largely ineffective in this model. Antiviral Res 2014;112:38-46

308 Florescu DF, Pergam SA, Neely MN, et al. Safety and efficacy of CMX001 as salvage therapy for severe adenovirus infections in immunocompromised patients. Biol Blood Marrow Transplant 2012;18(5):731-738

309 Paolino K, Sande J, Perez E, et al. Eradication of disseminated adenovirus infection in a pediatric hematopoietic stem cell transplantation recipient using the novel antiviral agent CMX001. J Clin Virol 2011;50(2):167-170

310 Marty FM, Winston DJ, Rowley SD, et al; CMX001-201 Clinical Study Group. CMX001 to prevent cytomegalovirus disease in hematopoietic-cell transplantation. N Engl J Med 2013;369(13): 1227-1236

311 Ljungman P, Ribaud P, Eyrich M, et al; Infectious Diseases Working Party of the European Group for Blood and Marrow Transplanta- tion. Cidofovir for adenovirus infections after allogeneic hematopoietic stem cell transplantation: a survey by the Infectious Diseases Working Party of the European Group for Blood and Marrow Transplantation. Bone Marrow Transplant 2003;31(6): 481-486

312 Legrand F, Berrebi D, Houhou N, et al. Early diagnosis of adenovirus infection and treatment with cidofovir after bone marrow transplantation in children. Bone Marrow Transplant 2001;27(6): 621-626

313 Mynarek M, Ganzenmueller T, Mueller-Heine A, et al. Patient, virus, and treatment-related risk factors in pediatric adenovirus infection after stem cell transplantation: results of a routine monitoring program. Biol Blood Marrow Transplant 2014; 20(2):250-256

314 Engelmann G, Heim A, Greil J, et al. Adenovirus infection and treatment with cidofovir in children after liver transplantation. Pediatr Transplant 2009;13(4):421-428

315 Refaat M, McNamara D, Teuteberg J, et al. Successful cidofovir treatment in an adult heart transplant recipient with severe adenovirus pneumonia. J Heart Lung Transplant 2008;27(6): 699-700

316 Saquib R, Melton LB, Chandrakantan A, et al. Disseminated adenovirus infection in renal transplant recipients: the role of cidofovir and intravenous immunoglobulin. Transpl Infect Dis 2010;12(1):77-83

317 Anderson EJ, Guzman-Cottrill JA, Kletzel M, et al. High-risk adenovirus-infected pediatric allogeneic hematopoietic progenitor cell transplant recipients and preemptive cidofovir therapy. Pediatr Transplant 2008;12(2):219-227

318 Nagafuji K, Aoki K, Henzan H, et al. Cidofovir for treating adenoviral hemorrhagic cystitis in hematopoietic stem cell transplant recipients. Bone Marrow Transplant 2004;34(10):909-914

319 Chakrabarti S, Mautner V, Osman H, et al. Adenovirus infections following allogeneic stem cell transplantation: incidence and outcome in relation to graft manipulation, immunosuppression, and immune recovery. Blood 2002;100(5):1619-1627

320 Heemskerk B, Lankester AC, van Vreeswijk T, et al. Immune reconstitution and clearance of human adenovirus viremia in pediatric stem-cell recipients. J Infect Dis 2005;191(4):520-530

321 van Tol MJ, Claas EC, Heemskerk B, et al. Adenovirus infection in children after allogeneic stem cell transplantation: diagnosis, treatment and immunity. Bone Marrow Transplant 2005;35 (Suppl 1):S73-S76

322 Papadopoulou A, Gerdemann U, Katari UL, et al. Activity of broadspectrum T cells as treatment for AdV, EBV, CMV, BKV, and HHV6 infections after HSCT. Sci Transl Med 2014;6(242):242ra83

323 Gerdemann U, Katari UL, Papadopoulou A, et al. Safety and clinical efficacy of rapidly-generated trivirus-directed $T$ cells as treatment for adenovirus, EBV, and CMV infections after allogeneic hematopoietic stem cell transplant. Mol Ther 2013;21(11): 2113-2121

324 Feucht J, Opherk K, Lang P, et al. Adoptive T-cell therapy with hexon-specific Th1 cells as a treatment of refractory adenovirus infection after HSCT. Blood 2015;125(12):1986-1994

325 Binn LN, Sanchez JL, Gaydos JC. Emergence of adenovirus type 14 in US military recruits-a new challenge. J Infect Dis 2007; 196(10):1436-1437 